\title{
Remote Sensing for International Peace and Security: Its Role and Implications
}

\author{
Ram Avtar ${ }^{1, *(\mathbb{D}}$, Asma Kouser ${ }^{2}$, Ashwani Kumar ${ }^{3} \mathbb{D}$, Deepak Singh ${ }^{1,4}$, Prakhar Misra ${ }^{5}$, Ankita Gupta ${ }^{6}$, \\ Ali P. Yunus ${ }^{7}$, Pankaj Kumar ${ }^{8}$ (D), Brian Alan Johnson ${ }^{8}{ }^{(D}$, Rajarshi Dasgupta ${ }^{8}(\mathbb{D}$, Netrananda Sahu 9 \\ and Andi Besse Rimba 10,11 (D)
}

1 Faculty of Environmental Earth Science, Hokkaido University, Sapporo 060-0810, Japan; deepak84_sse@jnu.ac.in

2 Department of Economics, Bengaluru City University, Post Office Road, Ambedkar Veedhi, Bengaluru, Karnataka 560001, India; asma11_isg@jnu.ac.in

3 Electrical and Instrumentation Engineering Department, Sant Longowal Institute of Engineering and Technology, Longowal 148106, India; ashwani.ist@sliet.ac.in

4 Department of Geography and Resource Management, The Chinese University of Hong Kong (CUHK), Sha Tin, New Territories, Hong Kong 999077, China

5 Research Institute for Humanity and Nature (RIHN), Kamigamo, Kita-ku, Kyoto 603-8047, Japan; mprakhar@chikyu.ac.jp

6 Graduate School of Information Science and Technology, Hokkaido University, Sapporo 060-0814, Japan; anki@m-icl.ist.hokudai.ac.jp

7 State Key Laboratory of Geohazard Prevention and Geoenvironment Protection, Chengdu University of Technology, Chengdu 610059, China; yunusp@cdut.edu.cn

8 Natural Resources and Ecosystem Services, Institute for Global Environmental Strategies, Hayama, Kanagawa 240-0115, Japan; kumar@iges.or.jp (P.K.); johnson@iges.or.jp (B.A.J.); dasgupta@iges.or.jp (R.D.)

check for updates

Citation: Avtar, R.; Kouser, A.; Kumar, A.; Singh, D.; Misra, P.; Gupta, A.; Yunus, A.P; Kumar, P.; Johnson, B.A.; Dasgupta, R.; et al. Remote Sensing for International Peace and Security: Its Role and Implications. Remote Sens. 2021, 13, 439. https:// doi.org/10.3390/rs13030439

Academic Editor: Ronald Estoque Received: 24 December 2020

Accepted: 20 January 2021

Published: 27 January 2021

Publisher's Note: MDPI stays neutral with regard to jurisdictional claims in published maps and institutional affiliations.

Copyright: (C) 2021 by the authors. Licensee MDPI, Basel, Switzerland. This article is an open access article distributed under the terms and conditions of the Creative Commons Attribution (CC BY) license (https:/ / creativecommons.org/licenses/by/ $4.0 /)$.
9 Department of Geography, Delhi School of Economics, University of Delhi, New Delhi 110007, India; nsahu@geography.du.ac.in

10 Department of Civil Engineering, Shibaura Institute of Technology, Tokyo 135-8548, Japan; rimba@unu.edu

11 United Nations University Institute for the Advanced Study of Sustainability (UNU-IAS), Shibuya-ku, Tokyo 150-8925, Japan

* Correspondence: ram@ees.hokudai.ac.jp; Tel.: +81-011-706-2261

\begin{abstract}
Remote sensing technology has seen a massive rise in popularity over the last two decades, becoming an integral part of our lives. Space-based satellite technologies facilitated access to the inaccessible terrains, helped humanitarian teams, support complex emergencies, and contributed to monitoring and verifying conflict zones. The scoping phase of this review investigated the utility of the role of remote sensing application to complement international peace and security activities owing to their ability to provide objective near real-time insights at the ground level. The first part of this review looks into the major research concepts and implementation of remote sensing-based techniques for international peace and security applications and presented a meta-analysis on how advanced sensor capabilities can support various aspects of peace and security. With key examples, we demonstrated how this technology assemblage enacts multiple versions of peace and security: for refugee relief operations, in armed conflicts monitoring, tracking acts of genocide, providing evidence in courts of law, and assessing contravention in human rights. The second part of this review anticipates future challenges that can hinder the applicative capabilities of remote sensing in peace and security. Varying types of sensors pose discrepancies in image classifications and issues like cost, resolution, and difficulty of ground-truth in conflict areas. With emerging technologies and sufficient secondary resources available, remote sensing plays a vital operational tool in conflict-affected areas by supporting an extensive diversity in public policy actions for peacekeeping processes.
\end{abstract}

Keywords: conflict resources monitoring; disease control and prevention; human rights; genocide tracking; human rights violation; geopolitics 


\section{Introduction}

Assuring the individual and collective well-being are the quintessential goals of any society. Different civilizations and societies develop certain principles and ethos that are binding as rules and regulations to their citizens. In return, the state (through its administrative machinery) strives to ensure its residents safety and welfare as a social contract [1]. The technology-oriented industrial revolution propelled the advent of the nation-state system and democratic thought. The Government's mandate and tools to deliver its functions continue evolving with time, demography, and technological innovations. The knowledge frontiers explore more scientific methods with considerable precision and accuracy to testify and ensure compliance with rules [2]. In the initial years, the power to master the earth's natural resources was the fundamental principle for economic expansion [3]. However, this uncontrolled growth became the reason for conflict (strategic control over oil and key mineral resources) among participating powers [4].

The rise of a scientific-industrial-military complex before and during the Cold War era had a lasting effect on the peace and tranquility of certain resource-rich and strategic regions. Although the techno-economic prowess aided development, the armed conflicts affected individual and community rights. For centuries, military commanders have sought out positions with a high elevation, such as mountains and ridges, to gain visual information about their enemies' locations and movements [5]. The First World War is widely regarded as the turning point in history that led to the wide popularity of many advanced techniques and weaponry systems. In particular, remote sensing gained prominence due to the application of high-altitude airplanes for aerial reconnaissance [6]. The aerial photographs were specifically used to locate enemy trenches and hidden positions, troop movements, supply routes, and depots, as well as to verify the effectiveness of artillery attacks against the enemy $[7,8]$.

The development of the man-made satellite was considered one of the largest technological breakthroughs in the military field [9]. The Cold War and Post-Cold War phase saw a vast expansion in such satellite deployments for international peace and security [10]. The United States Air Force's CORONA satellite program operated during the Cold War and collected over 800,000 aerial images of the Union of Soviet Social Republics (USSR), the People's Republic of China (PRC), and other countries and regions. As the platforms for remote sensing applications advanced by leaps and bounds, the sensors themselves also improved drastically. Initially, the CORONA satellite was only able to capture images from orbit with a spatial resolution up to roughly $12 \mathrm{~m}$ [11]. However, the spatial resolution of satellite images has shown drastic improvement to below one meter in recent years [12]. Multi spatio-temporal satellite data with local to global data acquisition can be applied in international peace and security in conflict zones. Several applications are shown in Figure 1.

In particular for military and conflict management, the application of remote sensing was initially limited to the technologically advanced nations, like the United States of America (USA) and the former USSR, as well as other countries with significant defense budgets. Satellite data have been used by the forces to identify terrains, rivers, ridges, populated areas, strategic installations, communication networks, etc. [13,14]. With time and technical advancements, remote sensing has also made significant contributions for less developed countries, such as Vietnam, Indonesia, Thailand, India, Cambodia, etc. The type of information accessible from remote sensing for peace and security depends on the sensor's specific properties and platform. Recently, with the availability of high spatio-temporal data, remote sensing technology was actively used in the detection of genocide in Darfur and human and drug trafficking in Afghanistan $[15,16]$. In addition to the applications in military purposes, aerial and satellite remote sensing have been significantly utilized for international peace through their role in preventing resource conflicts [17], disease control and prevention [18], human rights protection [19], and tracking genocide [20]. 


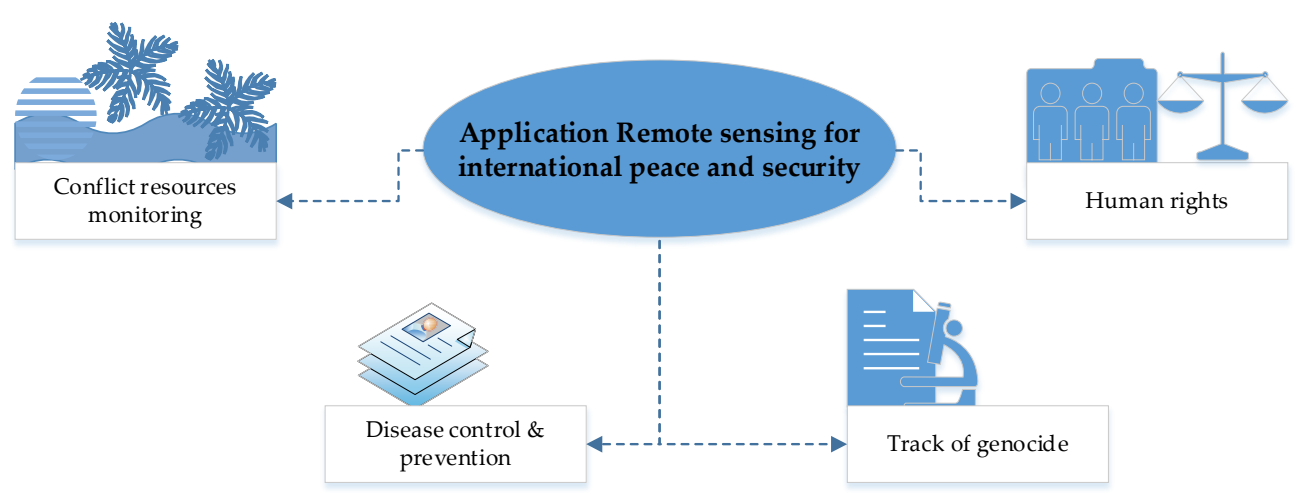

Figure 1. Applications of remote sensing for international peace and security.

Earth observation satellites and communication technologies offer precise and accurate means for remote monitoring of conflict zones. Some of the worst forms of human rights violations have been deeply rooted in either war zones (in resource-rich regions) or regions lacking basic resources like water and food [21]. It can be difficult to monitor these dangerous zones using ground information. However, remote sensing techniques can help to monitor such remote and dangerous zones without physical contact. Remote sensing has also been used for verifying international laws, treaties, and resolutions, e.g., for monitoring oil pollution sources [22], exploring renewable energy resources [23]. The technological development and rise in using sensors have led to the surge in remote sensing companies, aiding in the usage of data for the larger social and environmental safety. Geospatial techniques can provide useful information for the implementation of The United Nations Sustainable Development Goals (SDGs\#16, i.e., to promote peaceful and inclusive societies for sustainable development, and provide access to justice for all and build effective, accountable and inclusive institutions at all levels) [24,25].

Several approaches of remote sensing for military and civilian applications have been investigated [26]. These studies displayed remote sensing's utility for international peace and security both from a macro-perspective and micro-perspective, respectively. At the macro-level, the application of Geographical Information System (GIS) techniques in identifying the role of historical precedents in territorial disputes has shown valid results. For instance, in the European context, the application of GIS helped in finding the relationship between historical boundaries and conflicts [27]. For instance, studying the micro-level effect on issues like migration led to violent situations in the Goma City (the Democratic Republic of Congo) [28] and city-level consequences of Arab Spring in Jordan [29,30]. Furthermore, along with GIS techniques, other scientific tools like big data have been utilized to understand the intensity of such conflicts [31]. Remote sensing can also assist in understanding the issues emanating due to state classifications like ethnic fractionalization [32]. This, in return, can aid in the consolidation of socio-cultural theoretical frameworks of other humanities disciplines.

This paper builds on the previously mentioned potential importance of space-borne technologies in peace and security missions by highlighting the role of image data in near real-time and archived sources. Based on the available literature, we classified various studies and performed its meta-analysis for understanding the trends, potential, and impediments in applying remote sensing to the issues of peace and security. The selective analysis was conducted for the academic papers, research reports, and handbooks from a wide variety of sources, tracing the development of remote sensing applications in peace, security, and allied areas. We explored conflict resolution and monitoring as a theme by looking at disturbed and volatile regions and investigating instances related to a refugee relief operation, armed conflicts, genocide, human rights, peace-building, and issues crucial for preventing and controlling human disease. In each of these cases, we highlighted how remote sensing was utilized on the ground. 


\section{Methodology}

This scoping review is intended to cover an overlaying body of literature on earth observation technology in supporting emerging issues like sustainable development, human development, international peace, and security [33-35]. It presents a brief description of each application of remote sensing to these developmental and security issues at a global perspective [33-35]. Potentially relevant reference materials were obtained from research databases and appraised according to whether they included information on the previously mentioned themes. Thus, this review provides a broad introductory understanding structured across three nodes. First is the concept of peace and security. Second, the relevance of remote sensing to the issues of peace and security is introduced. Third, the contemporary status, challenges, and opportunities for peace and security through remote sensing are discussed. Figure 2 illustrates the flow of literature review for this study.

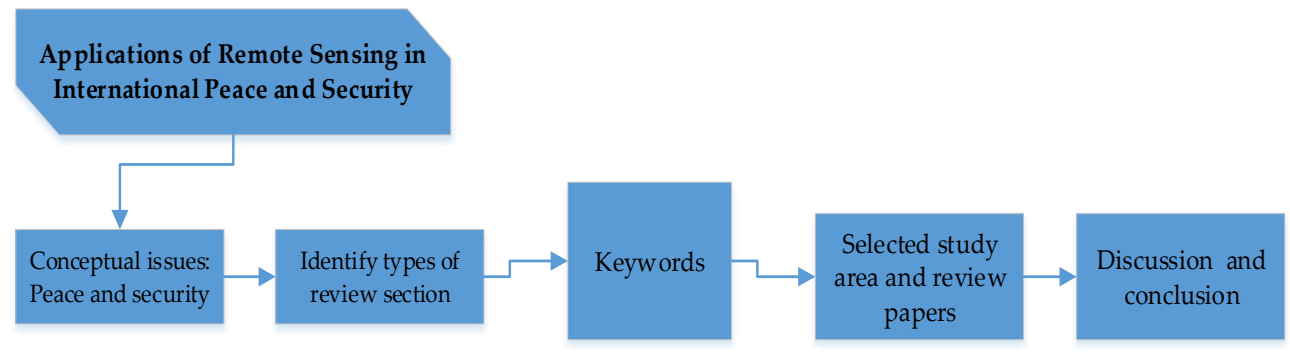

Figure 2. Flowchart of literature review.

\subsection{Conceptual Issues}

A conceptual analysis of the remote sensing approaches for peace and security has been carried out in Reference [36]. The conceptual issues can be mainly classified into two strands viz. definitions and cross-disciplinary interpretations.

'Peace' can be defined as a state or a period in which there is no war, or a war has ended $[37,38]$. However, there are many types of social settings where society does not experience peace despite the absence of war or conflict [39]. For instance, Thomas et al. [40] have argued that poverty is one of society's major threats. Countries with a high level of poverty, prohibition, intimidation, repression, terror, and other deterrents cannot be categorized as peaceful countries. Based on these observations, analysts working in peace and conflict management have varying definitions for peace from different perspectives. 'Security' is a state of ensuring protection from the direct/indirect notions and actions threatening an individual or, collectively, a group $[37,38]$. The international and regional organizations like the United Nations (UN), European Union, and other multi-lateral groups strive for attaining the standards of safety and security of individuals, countries, and regions.

Contextualizing the disciplinary connections becomes germane to broaden the understanding of the applications of remote sensing technology for peace and security. Branch [35] has identified the issues of measurement validity and selection bias with approaches in GIS technologies to the domains of peace and security in the studies of international relations. The measurement validity issues arise when the institutional structures are built over novel propositions with behavioral and pragmatic approaches that are not sufficiently absorbed by technical operational parameters (raster, vector, and other files) of the GIS interfaces [35]. During the analysis stage, the selection bias leads the discrepancies and prejudices between spatial and non-spatial information to creep into the study/system [35].

The successful application of remote sensing for peace and security depends on different kinds of datasets and how it is coded and analyzed within the framework of measurement validity and selection bias [35]. For instance, the large datasets about ethnic conflicts have the potential to overshadow the reasons contributing to their origins. The 
quantitative study of ethnic conflicts with a focus on micro-level studies has elucidated the essence of individuality during a conflict [41].

\subsection{Selection of Related-Articles and Keywords}

This study has approached the literature review extensively, exploring the application of remote sensing in international peace and security. Due consideration was given to the geographic distribution of the origin of articles, the discipline of the journal in which the article is published, online as well as offline, and the publishing type as open access or not, etc., using the Latent Dirichlet allocation (LDA) scheme. With an understanding that the topic should equally relate to science as well as the humanities disciplines, we leveraged our search to all the related disciplines. Among many literature database search engines, we primarily used the most popular ones viz.--ScienceDirect and Google Scholar, to explore scholarly articles from journals, conference proceedings, book chapters, etc. We searched articles with keywords such as "remote sensing" + "peace and security", bringing in 3240 results, and "remote sensing" + "natural resources monitoring" bringing in 854 results. Apart from that, we decided to use many online journals and research databases viz. ScienceOpen, Directory of Open Access Journals, Education Resources Information Center (ERIC), CIA World Factbook, Web of Science, Social Science Research Network (SSRN), ResearchGate, and Public Library of Science (PLoS) for exploring the scholarly articles.

While choosing an article for the study, we pondered with great attention that the document is relevant to remote sensing applications for international peace and security in domains such as conflict resources monitoring, disease control and prevention, human rights, and track of genocide, etc., as illustrated in Figure 1. After reviewing articles, we noted salient points of each of the articles and finalized a subset of articles most relevant to this review paper. A large number of papers were collected from a database of published articles. Several case studies were referred from the regions witnessing international conflict and bringing peace and security in the context of social dimensions. The literature identified that several troubled regions in Asia, Latin America, and Africa were studied through the use of satellite imagery. Two group discussions were conducted for three months among all authors of this paper. The first meeting resulted in deciding the types of keywords to be used while searching for relevant literature and the second discussion was focused on selecting the relevant examples.

The keywords identified were "role of remote sensing in international peace and security," "international peace and security with remote sensing," "geopolitics and remote sensing," "international conflicts resolution with remote sensing," and "remote sensingbased conflict resolution" were also chosen as search terms to gather more articles related to this study. To know the trend, the search was carried out using the same keyword for different periods. For example, a keyword phrase of "remote sensing for international peace and security" produced a total of 47,79, 126, 169, 227, and 252 search results for the period 1997-2000, 2001-2004, 2005-2008, 2009-2012, 2013-2016, and 2017-2020, respectively, while keeping the other search filters the same. Figure 3 shows the trend in searched papers. The rising numbers of published studies indicates the growing role of remote-sensing approaches toward international peace and security.

We also split the search results obtained in each of the four categories of remote sensing applications in peace and security, as mentioned in Figure 1. The total number of articles found on Google Scholar were 17,900, 13,700, 11,377, and 2510 for the categories of remote sensing applications in epidemics control and prevention, human rights, conflict resources monitoring, and genocide, respectively. However, category-overlapping was encountered among the searched papers since papers were often connected to more than one category. 


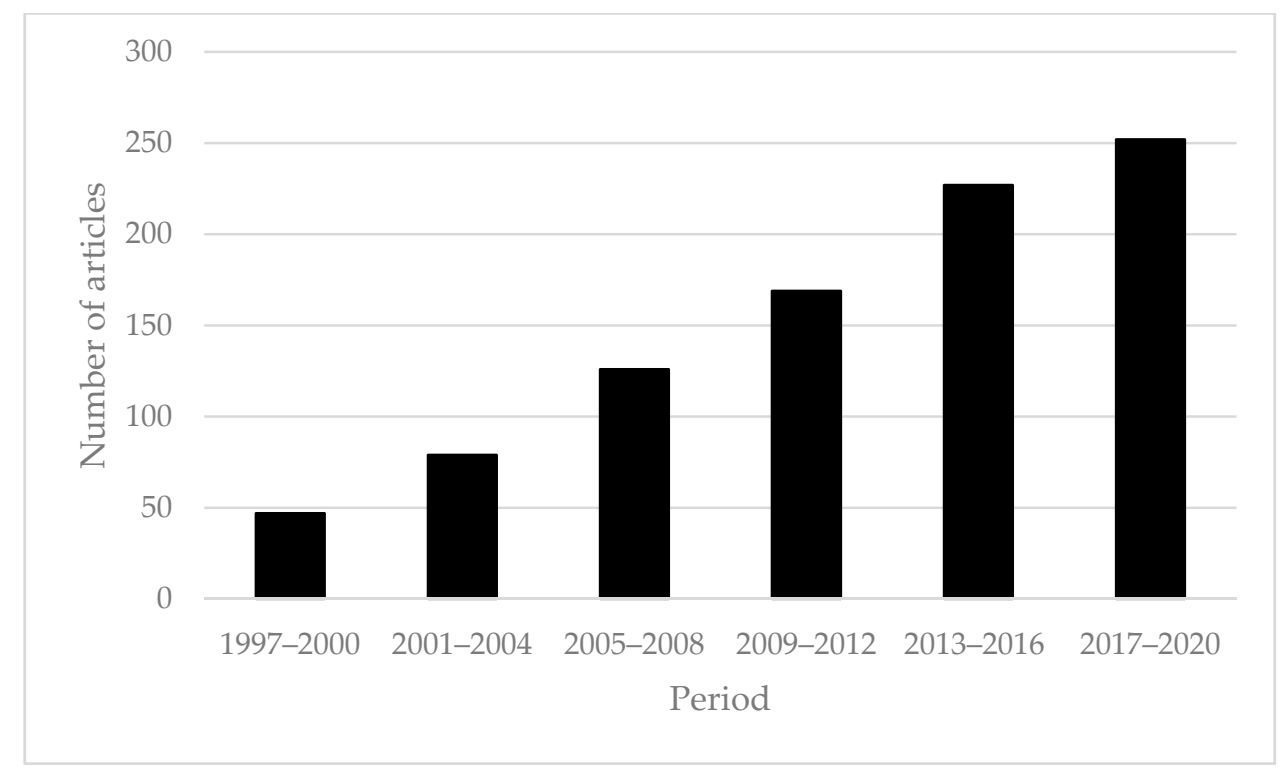

Figure 3. An increasing trend of the role of remote sensing in international peace and security.

A special focus was made for policy-oriented studies vis-à-vis key objectives of this study. To obtain a wide range of related articles, we added papers relating to conflict management with remote sensing, geopolitics and remote sensing, and other related reports. The unrelated papers were omitted after detailed reading. The final selected set of articles were examined carefully and the main findings were compiled with their shortcomings. Many papers did not meet our criteria for inclusion in the study. These papers were generally similar to other papers, or lacked statistically significant analysis, had shaky research methodology, deficient references, and lack of supporting evidence while drawing a conclusion, etc. Such papers were removed from our study's database.

\section{Results}

\subsection{Remote Sensing for Refugee Relief Operations}

Mapping displaced zones and refugee camps are vital to relief operations. The satellite data to map and monitor inaccessible conflict-riddled areas for relief work activities has been used by the United Nations High Commissioner for Refugees (UNHCR). It allows for tracking the affected communities and physical as well as environmental impact on the infrastructure at the refugee camps. For instance, the Sudan conflict left more than 2.5 million people displaced internally and approximately 600,000 refugees outside the country. Similarly, 5.5 million displaced Syrians were registered by UNHCR in Lebanon, Turkey, Jordan, Egypt, and Iraq. Furthermore, about 33,000 Syrian refugees were related in North Africa. According to UNHCR, to provide data on refugees-related numbers, food, and logistics, precise land use and individual refugee tents and buildings in the camp have been mapped.

Dalen et al. [42] and Bjorgo et al. [43] have employed European Remote Sensing satellite (ERS) and commercial very high spatial resolution (VHSR) satellite data from the Russian KVR-1000 sensor to demonstrate the pre-operational use of satellite remote sensing techniques. It helped in appropriately planning the strategies at the refugee camps. High-resolution is used for automatic mapping of refugee tents and camps by applying object-based image analysis [44]. Figure 4 shows the mapped tents of Al Zaatari refugee camps in Mafraq Governorate, Jordan using satellite images. As of 3 January 2013, a total of 11,966 shelters were detected within the 314 ha of the camp (Figure 4a). By 4 May 2013, a total of 28,243 shelters were detected within the 530.95 ha of the camp (Figure $4 \mathrm{~b}$ ), indicating that the number of shelters increased by about 16,000. Previously, United Nations Institute for Training and Research (UNITAR)/UNITAR's Operational 
Satellite Applications Programme (UNOSAT) found that the number of shelters is about 5138 on 15 November 2012. Thus, the shelters in the camp increased by $450 \%$ within less than five months. Besides, the total area of the camp grew from 216 hectares to 531 hectares in the same period, which is a $146 \%$ increase. This information, together with the data on the number of people living in each tent, is especially critical for assessing the food and medical aid. The number of refugees in each shelter can be inferred by the size of the structures and total population by multiplying the number of shelters in each camp [45].

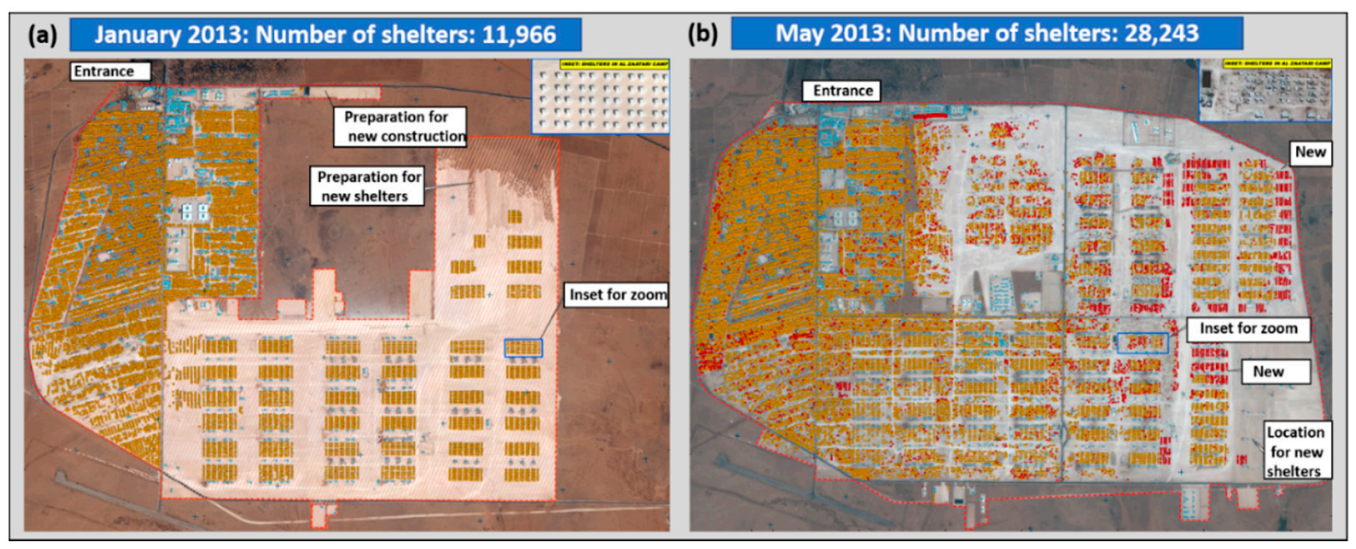

Figure 4. Satellite-detected shelters at the Al Zaatari refugee camp, Jordan (a) 3 January 2013 (WorldView-2 image), and (b) 4 May 2013 (WorldView-1 image) (Source: UNITAR/UNOSAT).

Nevertheless, there are difficulties in practice on object detection from medium-coarse resolution data. According to Quinn et al. [46], the following challenges are typical in refugee shelter mapping: (i) higher range of variation among refugees locations, (ii) small and clustered close-together shelters, and (iii) a higher log of accuracy is required owing to the critical decision support demanded. Automated machine learning models, such as Mask-Region Based Convolutional Neural Network (RCNN), can detect refugee settlements from high-resolution satellite images with an average Area Under the Curve (AUC) of 0.78 [46]. Apart from the relief operations, the satellites also aid site selection by providing baseline information of the terrain for refugee camps and also by identifying favorable areas with access to drinking water and firewood.

Images acquired from high-resolution satellite data can help in monitoring environmental degradation due to the movement of displaced persons from the conflict area. For instance, PlanetScope data shows an increase in the built-up area near the Kutupalong refugee camp in Cox's Bazar, Bangladesh. Figure 5a,b show the PlanetScope images acquired on 25 November 2016 and 15 November 2020, respectively. The development of the $32 \mathrm{Km}^{2}$ of Rohingya refugee camps destroyed also harmed biodiversity. These images acquired before and after the incident provide clear evidence of forest disturbance due to the development of the refugee campsite (Figure $5 a, b)$. Satellite data can be useful to provide information about environmental degradation due to international conflicts [47]. Knowing the size of refugee camps can help international agencies to plan and manage relief operations by providing logistic support, financial aids, and medical supports for these camps. 


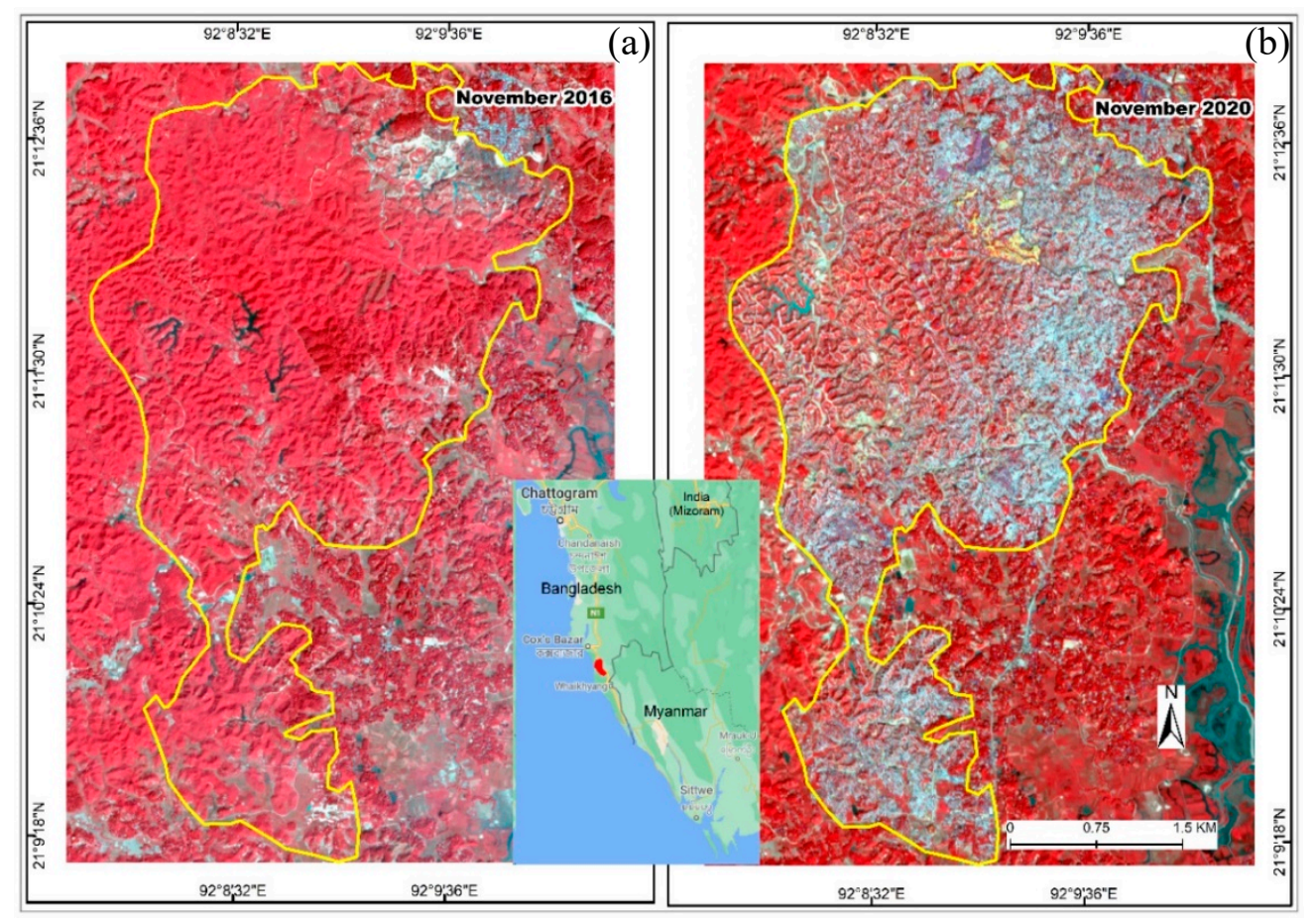

Figure 5. PlanetScope data of Kutupalong refugee campsite: $(\mathbf{a}, \mathbf{b})$ show the destruction of forest area due to the establishment of Rohingya refugee camps as observed from images taken on 25 November 2016 and 15 November 2020, respectively. [Source: prepared by authors].

\subsection{Remote Sensing in Armed Conflicts}

This technology has also been applied to quantify the causes of armed conflict and how such conflict can impact the environment. An example of this was shown in Brown et al. [16], where authors examined whether remote sensing could be used to confirm that the conflict in Darfur was a conflict across the resources among communities. Their study illustrated that remote sensing could be useful in testing claims, which are difficult to validate with more traditional information. These studies can be further extended with more granularity in studying the role of individuals and communities in the ignition of ethnic conflicts through local and regional databases [34]. Brown et al. [16] also examined how this technology can assist in reducing the devastating impacts on the environment during and after an armed conflict. War can cause extensive water and air pollution as well as the degradation of land and biodiversity. Such long-term environmental impacts might again contribute to future conflict if not addressed. Therefore, understanding environmental impacts exacerbated by conflict is fundamental in both conflict prevention and reconstruction. However, the impacts of the armed disputes and violence across the environmental domain, tending to be multifarious and, hence, extremely difficult to assess, especially during wartime. Nevertheless, remote sensing has augmented environmental impact assessment in conflict scenarios. This has greatly enhanced post-conflict reconstruction and rehabilitation [48].

The use of night-time light data to study armed conflicts has increased considerably over the last decade. It helps in identifying and analyzing the impact of different conflicts. For instance, the Suomi National Polar-Orbiting Partnership Visible Infrared Imaging Radiometer Suite sensor (NPP-VIIRS) has been used to evaluate the crisis in Sana, Yemen by utilizing the time series night-time light images (Figure 6). Jiang et al. [49] observed that between February 2015 and June 2015, the total night-time light of Yemen has decreased by $71.60 \%$ because of the severe conflict across the country. Levin et al. [31] utilized Visible Infrared Imaging Radiometer Suite (VIIRS) and Flickr photos to monitor the crisis development and refugee flow in Arabian countries. Change in economic and human capital can be observed using time-series VIIRS and Flickr photos. Their study concludes 
that the big data with remote sensing has the potential to provide unstructured but timely data on a conflicting situation in case of lacking a conducive approach for changes in environmental and geopolitical variations. Figure 7 shows a false-color composite (FCC) of VIIRS night-time brightness data acquired in October 2012 (in the red band), October 2015 (in the green band), and October 2018 (in the blue band) in Arabian countries. The areas with a decrease in night-time light after 2012 appear to have a red color. Most of the decrease of the night-time light is noticed in the Syrian region, which is related to the intensification of conflicts in the region. The areas with higher intensity of brightness during night-time on the observation dates emerge in a white color. The white color region shows the sites were not affected by the conflicts. VIIRS time-series data can be useful to provide essential information about economic changes in the region.

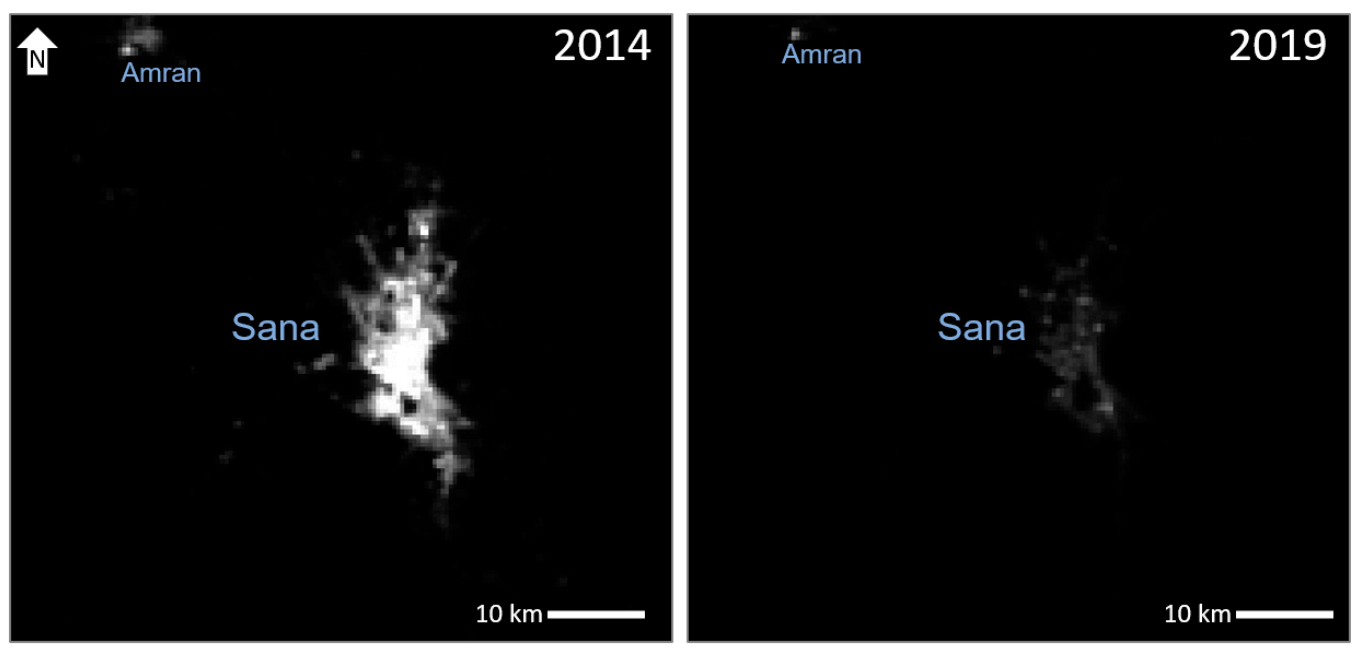

Figure 6. The Suomi National Polar-Orbiting Partnership Visible Infrared Imaging Radiometer Suite sensor (NPP-VIIRS) night-time light images of Sana, Yemen, during the years 2014 and 2019.

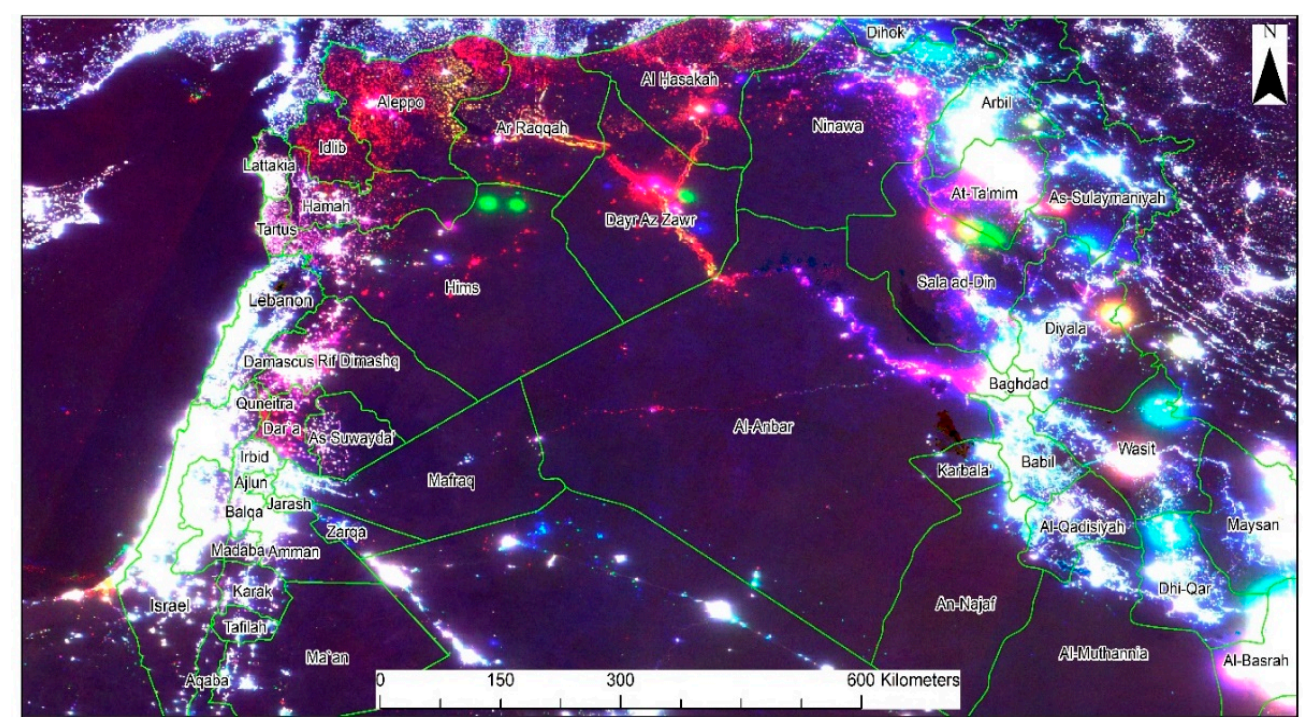

Figure 7. False-color composite (FCC) of Visible Infrared Imaging Radiometer Suite (VIIRS) nighttime data acquired in October 2012 (red band), October 2015 (green band), and October 2018 (blue band) in Arabian countries.

Remote sensing has also been utilized in assessing forest cover change aggravated by conflict. Forests are crucial in conflict situations because they are used as safe havens by both combatants and civilians. Poaching and deforestation in unprotected forests tend to 
increase during the conflict and, thus, threaten terrestrial biodiversity [50]. High spatial resolution satellite data can help determine forest cover change, a change in biodiversity, and species distribution. For instance, Georsevrski et al. [48] used multi-temporal Landsat imagery to determine forest cover change as a result of the Darfur crisis and Uganda clash. The study developed a disturbance index to monitor changes in South Sudan-based Imatong Central Forest Reserve (ICFR) located around Dongotana hills, and Uganda-based Agoro-Agu Forest Reserve (AFR) during the conflict (the 1980s-2001) and post-conflict (2003-2010). The study discovered there was more forest cover loss during the conflict period and that unprotected forests (Dongotana hills) experienced a huge loss compared to reserved forests [48].

Severe conflicts often result in attacks with bombs and firearms. Fires detected with the help of images from the satellite. It can be potentially utilized as an early warning signal, indicating humanitarian crisis like human-rights violations [46]. Armed conflicts disrupt human settlement and economic activities, as many people flee their homes to seek refuge. The refugees and internally displaced persons (IDPs) reduce environmental pressure in places of origin and increase pressure in places of destination. Remote sensing is a valuable tool in assessing these environmental pressures instigated by an influx of IDPs and refugees. In Sudan, Landsat data were used to locate burned structures among habitations around the ethnic violence periods [51-53]. In the Rift Valley province of Kenya, the United Nations Institute for Training and Research (UNITAR) used Moderate Resolution Imaging Spectroradiometer (MODIS) images to identify the areas showing signs of violence occurrences following Kenyan National Elections [54].

Remote sensing has also been used to detect macro-level transformations like land cover changes due to human displacement as well as to setup an association among the land tenure and land use land cover (LULC) classification [55]. If remote sensing techniques are cautiously applied within the limits of measurement validity and selection biases, then it is also possible to estimate the cultural loss, agricultural losses, land degradation and rehabilitation, disruption of water resources, and change in vegetation $[33,35,56]$. Using multiple satellite images and other explanatory variables, Levin et al. [57] indicated that more than $5 \%$ of 1073 World Heritage Sites (WHS) were in danger because of severe internal conflicts in which 25 are caused by armed conflicts.

Previously, in the context of monitoring of damage to the cultural heritage sites, manual satellite image interpretation techniques were used to assess the changes in the affected sites/area. These manual interpretation techniques were laborious and timeconsuming. However, the automatic classification of satellite imagery and the change detection methods are promising to monitor the changes recently [58]. In other studies, high-resolution multi-temporal satellite imagery was used to understand the impact on environment at the Sudanese Zam Zam IDP camp, which was established as a result of the Darfur crisis [59]. Figure 8 shows the satellite images of burned sites damaged in the 2011 Sudan conflicts. Figure 8e clearly shows the damaged and non-damaged structures in the Tajalei region of Sudan.

Figure 9 shows another case study in the conflict zones of Syria, where an archaeological site was damaged during the Syrian civil war. Figure 9a,b show the encroachment around the Abbasid Palace and its peripheral area using satellite data before (8 April 2011) and after (1 July 2016) the conflict, respectively. The former Abbasid Palace compound, Syria, which was one of the archaeological sites, is now covered by a modern building visible in satellite data [60]. The temporal satellite data shows the change in the built-up area due to the Islamic State of Iraq and Syria (ISIS) activities. On the city scale, the highresolution satellite data have been used for mapping ambient light during the night in urban environments for security [61]. 


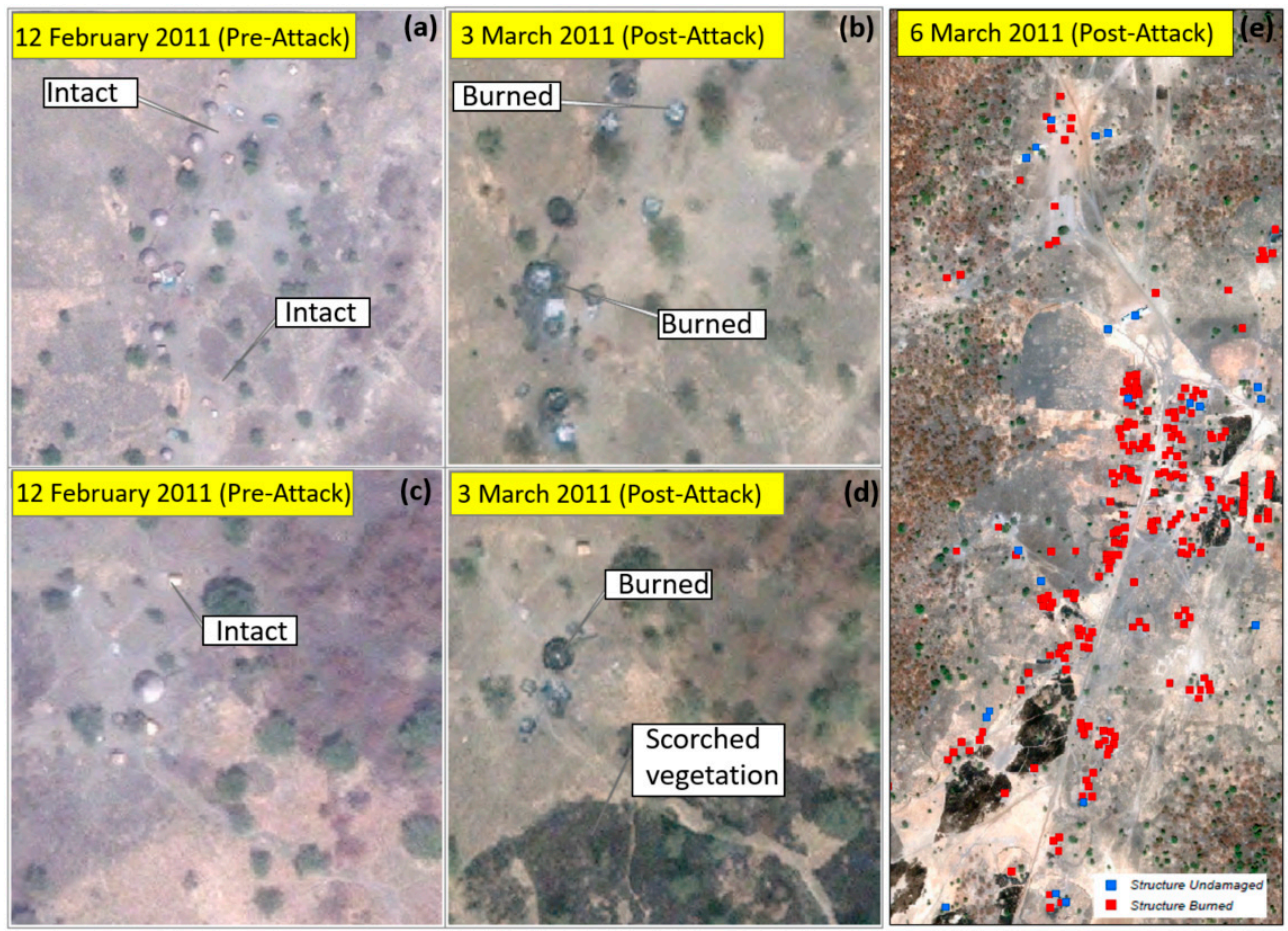

Figure 8. Satellite images of conflict zones in Sudan showing evidence of arson attacks: $(\mathbf{a}, \mathbf{c})$ preconflict images of 12 February 2011 showing intact buildings (b,d) are post-conflict images on 3 March 2011 showing burned structures in the Maker Awat region. (e) show the damaged and non-damaged structures of Tajalei region mapped from Worldview 2 imagery on 6 March 2011. [Source: UNITAR/UNOSAT].
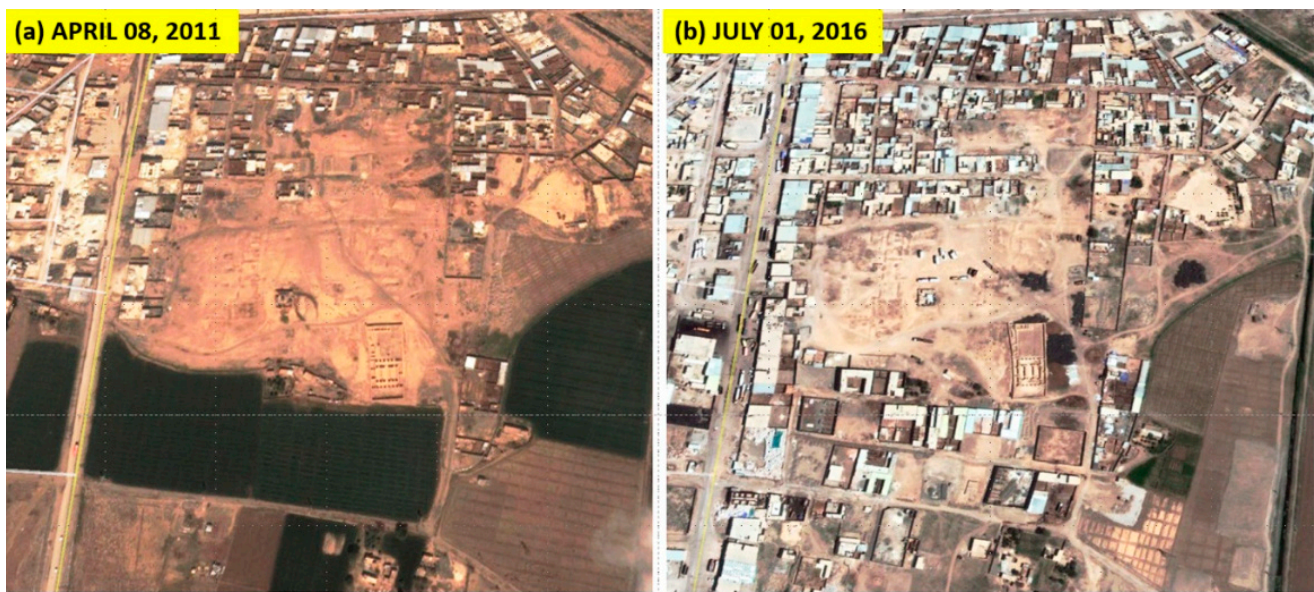

Figure 9. Satellite images of conflict zones in Syria: $(\mathbf{a}, \mathbf{b})$ the Abbasid Palace area encroachment as observed from images taken in April 2011 and July 2016, respectively [Images are reproduced from Casana and Laugier et al. studies [62] Image sources: GoogleEarth images date of access: 28 November 2020].

In the domain of conflict in resource-rich regions, the oil production of ISIS has been estimated using remote sensing techniques for geopolitics and energy security [62]. The politics of carbon sequestration to awareness about the potentials of negative emissions have been discussed in Reference [63]. A security assessment model for geo-energy that quantifies geo-strategic oil energy security by China for oil pipeline construction in Russian pacific (from 1995 to 2010) has been rebuilt [64]. With inspiration from previous work on methodologies in political geography, a linkage between politics and language has also 
been examined in Reference [65]. The converging applications of emerging technologies like artificial intelligence and remote sensing through autonomous drones for international peace and security have been discussed in Reference [66].

The contemporary geopolitics in terms of the digital representations of space such as Google Maps, OpenStreetMap, geopolitical properties, and geopolitical subjectivity have been discussed in Reference [39]. The geopolitical remote sensing has been discussed with an emphasis on aerial data collection rather than ground-based data collection [67]. On a large scale, country-specific applications, the imagery captured using commercial satellites have been used for the security of Canada [68] and use of the field spectroscopy for security in Cyprus [69]. The geopolitical approaches to outer space activities and the effect of launching several satellites into space have been discussed in Reference [70].

A survey on the scope of remote sensing technology in assessing the influence of conflict has been carried out by Witmer [71]. A case study on the Arab Spring was carried out to quantify the conflict level using remote sensing techniques [31]. A survey on the scope of remote sensing approach in assessing the influence of conflict has been carried out by Witmer [71]. Another use of remote sensing technology in the region for monitoring of conflict and damage to the heritage sites using satellite data. Previously, manual satellite image interpretation techniques were used to assess damage or changes in the area. These manual interpretation techniques were laborious and time-consuming. However, the recent automatic classification of satellite imagery and change detection methods are promising to monitor the changes [58].

According to Galtung et al. [39], there are many types of social settings that are not considered as war or conflict. Remote sensing techniques have played an instrumental role in supporting complex emergency cases from time to time. Zhang et al. [72] used a high-frequency mixed-mode surface wave radar to detect ships for international peace and security purposes. Unmanned Aerial vehicles (UAVs) equipped with a camera and a ground-based sensor has been used for landmine surveying during humanitarian demining [73]. The recommendations based on an extensive review of global peace, security, and development have been made in Ibrahim et al. studies [74].

Another potential utilization of satellite remote sensing in border armed conflicts is tracking compliance with peacekeeping processes. Due to the recent incidents of violence across the international border of South Sudan and Sudan, the UN security council enacted a significant resolution (Resolution-2046). This resolution requires the governments of these two countries to meet several conditions to ensure peaceful settlements of international disputes, including an outright withdrawal of the respective armed forces from their sides of the border or consequences of sanctions under U.N. Charter's Article 41. However, the satellite-based tracking of border areas shows that both nations did not comply with the UN resolution even after the deadline, thus, allowing for the implementation of strict sanctions against both countries [75].

Furthermore, high-resolution satellite images showing aircraft, tanks, trucks, and troops in strategic locations indicate compelling evidence of soon-to-occur attacks. If monitored in near-real-time, such activities can be recognized as an early warning system for preparations and alert civilians about the danger of the attack. A classic example is from Sudan, where satellite-based tracking of artillery troops in a striking distance of Kurmuk area averted a potential disaster by issuing a human security warning that enables civilian people to flee away before the massive bombs strike [76].

On a similar note, in the peace talks between China and India after the conflict in Galwan valley (in 2020), the tensions cease to end after multiple negotiations from both sides about an agreement to withdraw troops from border areas. The data from satellite and aerial images confirmed the disengagement of troops from the border zones, which helped prevent a war-like situation amid COVID-19 peaks [77]. 


\subsection{Remote Sensing in Tracking the Acts of Genocide}

Genocide is the intentional mass murder or destruction of a people group and is among the most severe acts of human rights violation. Genocides have occurred in several regions, but, in most cases, these mass murders are conducted secretly and are only discovered afterward [78]. Remote sensing appears promising vis-à-vis international security from genocidal issues. An analysis of two case studies by the Genocide Studies Program at Yale University demonstrates the usefulness of remote sensing in tracking genocidal acts, corroborating eyewitness testimony, and supplementing reports by independent organizations. In addition, when the world is facing challenges in countries and regions like Syria, Myanmar, and the Democratic Republic of Congo (DRC), it can help to assess the severity of acts of genocide and population displacement arising from the armed conflicts [78].

Schimmer Russell [79] reported how a single Landsat image (taken four days after the announcement of results of the East Timorese independence referendum in 1999) was used to identify the concentrations of ground fires to assess the extent of destruction by pro-Indonesian militant forces. Schimmer's work found correlations between eyewitness reports and the location and pattern of fires identified from satellite images. The data also located other areas around the image-based boundaries, which were most likely subjected to related demolition but with missing reports. Using satellite imagery, the researchers showed that the fires were mainly concentrated around the capital city of Dili. A United Nations Security Council delegation that visited East Timor after the referendum, and, other eyewitnesses, reported that much of Dili had been burned and ransacked [79]. Expanding the analysis to the rest of East Timor, the researchers were able to positively identify locations of fires across the country and subsequently corroborate this with eyewitness and other independent reports. This study demonstrated how remote sensing data can be used alongside eyewitness accounts to ascertain the extent of destruction in these types of situations. It should, however, be noted that there was some fortune in the timing of the capture of the image. As the author notes- "It is rare that an image both temporally and spatially coincides with a place and moment in time under research" [79]. In another study, trends in vegetation cover change were directly related to variations among landuse caused by the genocidal activities in Darfur. The researchers used rainfall data and vegetation indices (NDVI) obtained from MODIS Terra and Satellite Pour l'Observation de la Terre (SPOT) satellites [80]. In this particular case, the remote sensing data were applied to illustrate the temporal changes in vegetation cover (2000-2003).

The availability of satellite-clusters with short revisit periods are providing rapid alert of human right violations associated with genocide. In the Rakhine state, the crisis is between Rakhine Buddhists and ethnic Muslims and several villages belonging to the latter have undergone arson while those belonging to the former are usually standing intact. Satellite analysis was associated with the information on the habitations in Myanmar, which indicates that approximately 392 towns and villages from a total number of 993 were affected (Figure 10). A UNITAR study reported the use of WorldView-3 data to identify destroyed villages in the Northern Myanmar's Rakhine state.

Marx et al. [81,82] developed a methodology for detecting burned villages in the Rakhine state of Myanmar. Burned or damaged villages can be identified by sudden drops in near-infrared reflectance between two observation dates. Village huts with dried plantation roofs have a low NIR reflectance when damaged or destroyed. The researchers utilized the short repeat cycle of Planet's Dove satellites to compare and detect changes in the near-infrared band over rural household structures belonging to adjacent Buddhist and Muslim communities. This enabled them to identify the potential destruction of villages and inform agencies like Human Rights Watch. The information can then also be used for corroborating eyewitness accounts for the destruction by refugees. Madden et al. [83] combined qualitative data collected from personal narratives with the data obtained using the Geographical Information System (GIS) technologies to study mass atrocities in the northern part of Uganda. This study shows the role of GIS for cartographic functions and 
geo-visualization. The previous case studies demonstrate the usefulness of remote sensing data to track cases of population displacement and genocide, supplementing independent eyewitnesses and other reports.

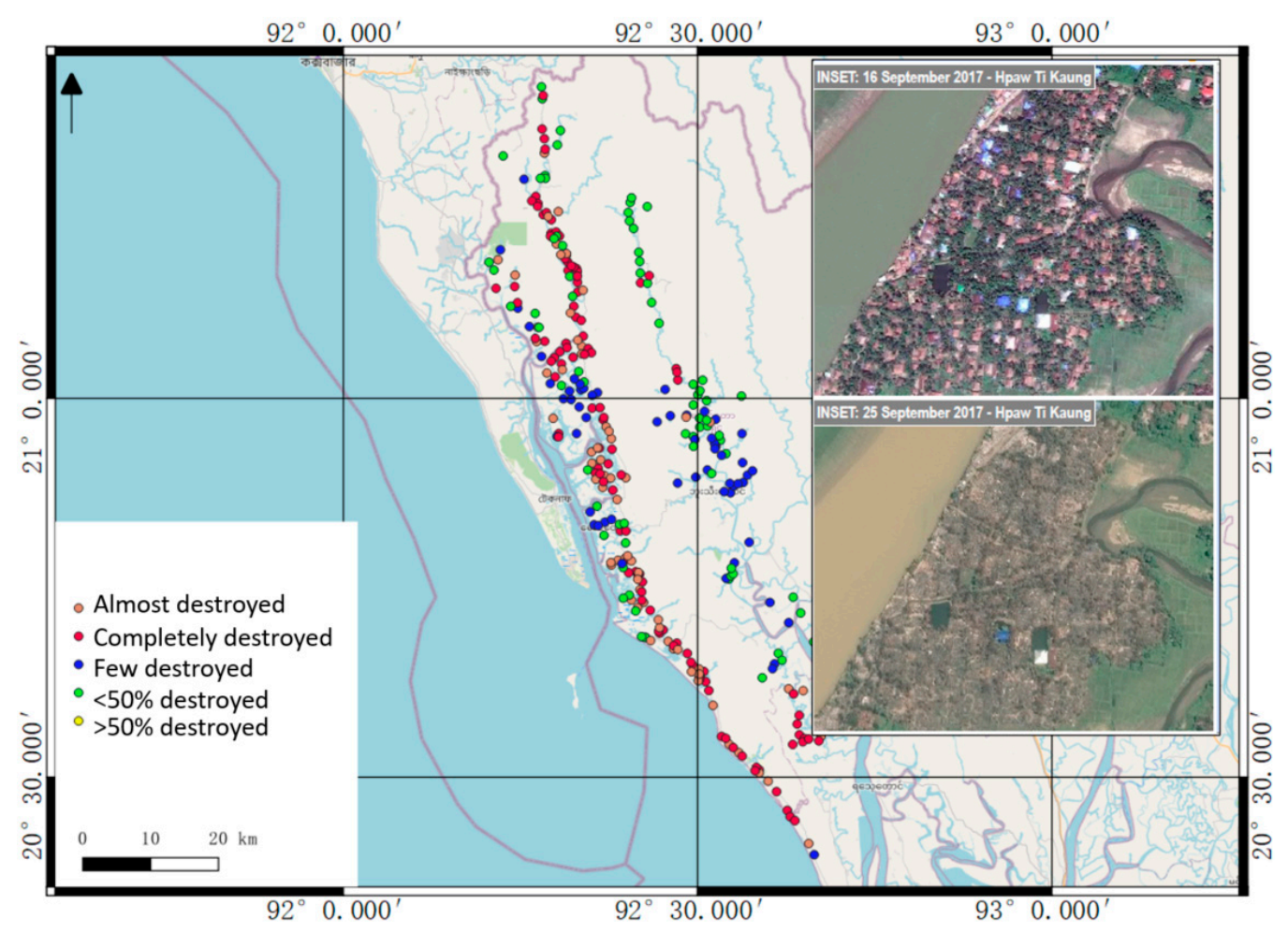

Figure 10. Areas of satellite-detected destroyed or otherwise damaged settlements in Northern Rakhine State in Myanmar. Inset figures showing destroyed villages (Source: UNITAR/UNOSAT).

\subsection{Remote Sensing in International Peace Missions}

Remote sensing technologies can contribute to various components of the fulfillment of the peace process. GIS can help to provide spatial information about homicides, conflictrelated deaths, violence, etc., which can help the implementation of SDGs\# 16 i.e., to promote peaceful and inclusive societies for sustainable development, and provide access to justice for all and build effective, accountable and inclusive institutions at all levels [24] Satellite data can provide valuable evidence in remote or conflict zones where field visits are difficult [71]. Remote sensing data can be an effective tool for resolving running disputes at international borders. By addressing the discerning factors causing the conflict in monitoring the border situation remotely can be done through the deployment of remote sensing techniques. It can be used as the identifiable indicators, with little warning signs before a major crisis erupts [71]. Verifying the agreements put forth in conflict zones is an important aspect of handling international disputes of this kind [22]. Satellites have always been identified with national technical means of verification with increased cooperative missions at an international level that are associated with it. For instance, satellite images have been widely used as the source of verification in decommissioning of facilities, disengagements, storage, and destruction that are vital in the peace process-from negotiating to overseeing implementation to post-conflict peacebuilding processes.

\subsection{Applications in Peace and Conflict Areas}

Remote sensing can also aid in peace and conflict policy formulation with the identification of exploited natural resources [23]. For example, in the context of the DRC, the extraction of natural minerals, such as concentrated columbite-tantalite and cassiterite, has been discussed [52]. Both these minerals are used to build components of electronic 
products and have been in demand because of their application-specific competitive pricing in the international market. This work has looked into the possibility of detecting resource-based conflict before they inflate into a violent confrontation.

Gorsevski et al. [48] estimated 2000-armed conflicts that occurred about the same time when the market value of these minerals was at its peak. To monitor the extraction of concentrated columbite-tantalite and cassiterite, a workflow based on object detection and GIS analysis was adopted. Site-activity indicators such as roads, settlements, or rivers were used to narrow down relevant areas for analysis [84]. The object-based multiscale image analysis approach was also able to locate mining areas in North and South Kivu. However, the researchers did not discount the possibility of overlooking small scale mining areas. Through this process, the researchers argued that remote sensing could aid in the development of early warning systems for resource-based conflict by monitoring the extraction of conflict resources that can result in the prevention of conflict escalation and adoption of peace and security policies that comprehensively address the roots of resourcebased conflict. The study demonstrated that remote sensing could be highly useful in monitoring resource extraction activities in conflict-affected areas.

Another case where remote sensing was applied for monitoring resource-related conflicts was in the Afghan drug industry. The researchers used remote sensing and population survey data to develop a virtual, rural Afghan population, where poppy is cultivated [15]. The virtual population developed by the researchers was used to model illicit economic activities in the country torn by complex conflicts. A multi-agent model helped to identify the spatial distribution of pertinent agents/actors involved in the Afghan drug industry. This information benefits the monitoring of the trade by relevant peace and security actors. This example shows how qualitative data collected from the narrative description from natives was combined with remote sensing data to build a virtual rural map and, hence, was successfully utilized to accomplish conflict resolution in Afghanistan.

Besides these applications, radar satellites with Synthetic Aperture Radar (SAR) technology and VIIRS nighttime images can identify shipping vessels and the possible nature of their activity. Detection from SAR is based on the principle that the backscatter from the 3-dimensional planar surfaces of a ship along with the overall size can be used to distinguish them into oil-tankers, shipping boats, patrol vessels, and armed naval ships. Large ships or clusters of small-boats also emit light, which makes their detection possible in the day/night band of VIIRS. Recently Elvidge et al. [85] have shown detection of low light emission from small fishing boats (smaller than $19 \mathrm{~m}$ in length) by using a combination of nighttime light imagery. By cross-matching these detections with tracking data from Automatic Identification System (AIS) and Vessel Monitoring Systems (VMS), the "dark fishing" vessels can be identified, which have intentionally shut down their tracking devices for a considerable time. This system is used by the Global Fishing Watch to identify illegal fishing in international waters or foreign maritime zones.

The use of chemicals and explosive weapons can have devastating impacts on land, water, and air. It is hard to monitor these effects with the naked eye. Nevertheless, remote sensing helps detect both the short-term and long-term impacts of these weapons. It can help to determine the effects of a crisis on aquatic life and water quality. Besides, it is very pertinent in assessing the geomorphologic impact of the usage of explosive weapons. Remote sensing can also identify changes in soil texture and content as well as changes in the landscape. It can also be used to identify landmines during the post-conflict phase to minimize further damage. Moreover, remote sensing can be used in monitoring air pollution during armed conflict, which has been trivialized for a long time. After the devastating Gulf war in Kuwait, remote sensing was utilized to monitor sand encroachment and land deformation due to the usage of explosive weapons [86].

A case study of forestry conflict in Sumatra, which is a large island in Indonesia, has been presented in Yasmi et al. [87]. The authors discussed how remote sensing techniques have been helpful in conflict crisis resolution between the communities and the associated organizations. The challenges in conflict management have also been presented exhaus- 
tively. The management of cross-border conflicts using remote sensing data collected with Google Earth layers is a good example highlighting the importance of remote sensing toward international peace and security [88].

\subsection{Remote Sensing and Human Rights}

From 2006 onward, the American Association for the Advancement of Science (AAAS) Geospatial Technologies and Human Rights Project has globally aligned with human rights organizations. The remote sensing data has been used for human rights in two distinct ways, namely documentation and analysis, and as scientific evidence in the court of law [89]. In courts, scientific proof has been used to supplement other, more conventional evidence. In the context of the former Yugoslavia's case, the satellite imagery was used to validate the witness accounts of civilian killings by the International Criminal Tribunal (ICT). The Amnesty International [89] has suggested using remote sensing as evidence in courts for bringing the perpetrators to the book [89]. Still, there is a lack of consensus on the admissibility of such evidence in different courts [90]. In addition, this has made it difficult to make generalized conclusions about the consistent use of remote sensing in the field of jurisprudence.

Various remote sensing techniques viz. radiometric, SAR, aerial photography, Light Detection and Ranging (LiDAR), and thermal imaging, etc. play a vital role in various aspects of human rights, such as equality, freedom, education, dignity, prosperity, justice, and speech. Figure 11 depicts the interconnection of remote sensing techniques with the various aspects of human rights. Although remote sensing platforms provide useful data, it can be interpreted differently by different users and algorithms. During a dispute between Nigeria and Cameroon before the International Court of Justice (ICJ), the remote sensing evidence presented before the court had conflicting interpretations [90]. To establish the legitimacy of using satellite data in legal proceedings, it is important to create universal standards for the interpretation and validation of data across different courts worldwide. To date, it has been used on an ad hoc basis by the European Court of Human Rights for the conflict between Russia and Georgia over South Ossetia, the African Commission, and the African Court of Human and People's Rights in the case of forced evictions in Zimbabwe, and the International Criminal Court in the case of human rights violations in Darfur [91].

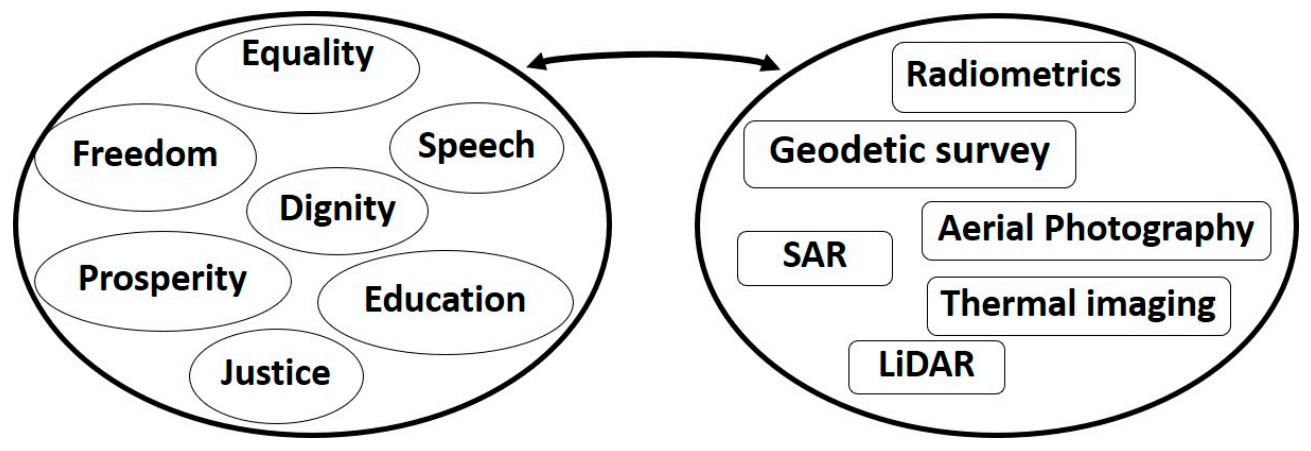

Figure 11. Remote sensing and human rights [15].

Different tools are being used to document and understand human rights violations. For instance, the imagery processed from Afghanistan in 2006-2007 supported the findings of Physicians for Human Rights on the suspicions of mass graves in Northern Afghanistan [92]. On the other hand, the review of different images in Myanmar compared to the reports on attacks against civilians in Karen State by the government in 2006-2007 and 2009 provided proof of destruction and the construction of new military occupation camps [93]. In collaboration with the Amnesty International and the US Holocaust Memorial Museum, AAAS has also looked into evidence of attacks against civilians in Chad and Darfur, Sudan. In 2008, AAAS and Amnesty International in Georgia assessed the damage of the region of Tskhinvali in conflict with Russia. In 2005, the Zimbabwe Lawyers for 
Human Rights used remote sensing techniques in assessing the damage caused by the demolition of houses by the government [89].

In the human rights field, remote sensing has opened a new window of opportunity to reach into areas of the world that are not easily accessible either for geographical or political reasons. In these circumstances, remote sensing data serves to supplement and validate reports of human rights abuse and violations coming from the ground. For instance, satellite images confirmed the increased number of prison camps in North Korea over the years [94]. It has also been ingeniously used to create a web resource serving as an open-source of information for human rights violations in places like Pakistan and to identify the location of individuals at risk [95]. These events and attributes suggest that non-governmental actors have been active in using remote sensing techniques to identify and report on human rights violations. There are often three common components of humanitarian remote sensing projects: (1) they usually involve a combination of different actors, including the provider of images, (2) they consist of imagery analysis experts partnering with an advocacy organization, and, (3) typically, the funder is directly involved with the project [96].

Looking at the collaboration networks among various actors and agencies, the Satellite Sentinel Project (SSP) is an important example [97]. The project is funded by the American actor George Clooney's organization Not On Our Watch [98]. The goal of the project is to prevent the return of all-out civil war between South Sudan and Sudan. In the SSP program, a non-governmental organization is working with a private donor with aid through remote sensing for assessing, deterring, and documenting human rights violations [97]. For SSP to accomplish this goal, they have partnered with the imagery provider DigitalGlobe and their imagery analysis experts. DigitalGlobe's high-resolution commercial satellites, known as QuickBird, WorldView-1, and WorldView-2, pass over Sudan and South Sudan in order to understand the impact on civilians. After collecting the satellite images, analysts at DigitalGlobe work with the rights-based group called the Enough Project to analyze imagery and ground sourcing information. If experts detect human rights abuses, then the project releases a report to the press and policymakers to generate a rapid response when it comes to human rights abuses and human security concerns [96].

An example of the SSP using remote sensing to document atrocities is the Mass Atrocity Alert report called Cover-Up: New Evidence of Three Mass Graves in South Kordofan. With the analysis of the imagery and eyewitnesses who admitted to seeing the government of Sudan's militia groups dumping white body bags in the area, SSP analysts were able to conclude that the suspected areas were the locations of mass graves. After concluding that these areas were, in fact, efforts by the government of Sudan to cover up large-scale burial operations, SSP immediately sent out Mass Atrocity Alerts in hopes of alerting the press and policymakers of the human rights abuses happening in the area [97]. According to Wang et al. [96], the Satellite Sentinel Project [97] is one of the few non-governmental organizations that can afford the high cost of near-real-time imagery from high-resolution commercial satellites. It is not surprising that most human rights organizations and advocacy groups are unable to use remote sensing techniques to uncover and report on mass atrocities in locations where international crimes like genocide and other gross human rights violations are taking place [96].

\subsection{Remote Sensing for Disease Control and Prevention}

With accelerating global warming and climate change combined with human-animal conflict, there is a rise in communicable and non-communicable diseases. Infectious diseases such as HIV / AIDS, Ebola, SARS, Zika, and COVID-19 posed a challenge to the global peace order [99]. The spread of a disease, whether it is within a developed or a developing country, can have severe security repercussions. A widespread outbreak can shut down a country, causing both fear and an economic downturn. Consequently, improvements in methods by which the government can identify and stem the outbreak of disease early on are necessary. Remote sensing has been suggested as such a method, 
using different characteristics of diseases to identify either the outbreak or possibilities of risk. It can be used for monitoring, surveying, or conducting a risk analysis of vector-borne diseases [100]. Disease mapping once believed to be a final frontier for remote sensing [101] has come a long way with better spatio-temporal availability of remote sensing platforms and socially sensed datasets [102,103].

Remote sensing has been used during studies done on malaria [102], Lyme disease [100], Rift Valley fever, and the COVID-19 pandemic [101,104-109], among others $[101,104,107-109]$. However, it should be noted that these studies have only been done post facto, as a way to verify whether different remote sensing indicators matched the actual occurrence on the ground. Subsequently, this means that these methods have never been tested ex-ante, either as an outbreak was occurring or to prevent an outbreak from happening. An example of such a study concerned the spread of Lyme disease in the Northeastern United States [110]. Remote sensing was used in several ways to examine the "map relative tick abundance on residential properties by using Landsat TM-derived indices of vegetation greenness and wetness" [110]. Essentially, this study aims to identify risk factors for Lyme disease exposure in different populated areas. The study extracted information about contiguous forest patches using Landsat TM data. Contiguous forest patches are a favorite location of white-tailed deer, and its illegal transfer from the region. Furthermore, it was examined whether these were areas for human host exposure. Using these factors, as well as examining the suitable "tasseled cap greened and wetness," which measures the greenness and wetness of an area, residential areas harboring abundant tick populations were identified. The researchers could then determine the areas that were most at risk of exposure to the ticks and, therefore, Lyme disease [110].

Another example is the case of cholera in Bangladesh. Using remote sensing, the researchers looked for sediment loads within the Bay of Bengal, which contain nutrients that could support the plankton that could contain Vibrio cholerae [110]. The researchers also examined the height, temperature of the sea surface, and the amount of chlorophyll within the water to determine the possibility of there being Vibrio cholerae in the Bay (Ibid.). Since this study was done after the event, the different factors showed a positive correlation in the appearance of cholera in the water. By completing this research, it is hoped that remote sensing could be used to examine the existence of cholera within the water before an outbreak happens or within its beginning stages. Both the above studies mentioned above were done after a disease outbreak. Currently, the Japanese Aerospace Exploration Agency (JAXA) operates the Public-health Monitor and Analysis Platform (JMAP) for surveillance and prediction of malaria and cholera in African countries [111]. However, the reliability of remote sensing-based predictions is still unclear for this type of investigation. Furthermore, the hope is that this type of analysis can be expanded to include other water-borne and soil-borne diseases through model analysis to identify warning signs of a disease outbreak.

\section{Discussion}

Remote sensing applications have come a long way, ever since the testing of the Transit (1960), which is the United States Navy's first military navigation satellite. The defense applications have expanded leaps and bounds from intelligence gathering, positioning, and navigation to communications. This technique has become essential in many aspects of international peace and security $[112,113]$. The costs of using satellite and other imagery data are very high, and, therefore, such techniques are not accessible to all actors playing a role in peacemaking and peacebuilding processes.

Applications of remote sensing techniques have been improved with the advancement of sensor technology and processing algorithms over time. Table 1 shows the major case studies related to remote sensing applications in peace and security in the last two decades. Landsat data has played a vital role and is popular among most of the major case studies presented in Table 1 because of free access since 2008 [71]. There were fewer case studies before 2010 and most of these studies used conventional visual image interpretation techniques using common satellite data. The number of published papers increased after 
2010 and used advanced image processing algorithms with advanced sensors. Machine learning algorithms have recently become popular to process satellite data with better resolutions. The use of advanced sensor data with advanced spatio-temporal strengths can provide more accurate information about incidents. This information can help to develop an early warning system to prevent conflicts. However, there is still a need to establish a standard methodology and code of ethics [96] to use these scientific data as a source for international cooperation and international courts of law.

For the operations of law enforcement agencies, the satellite data can be used as a piece of credible evidence in a court of law. However, since there is a paucity of legal criteria for interpretation and admissibility of remote sensing imaging, the legality of its use as uncontested evidence requires refinements in country-specific bye-laws. As indicated, the issues of measurement validity and selection biases require assessment through a multidisciplinary lens. Where the local and standard definitions, classifications, and constructs regarding socio-cultural and historical aspects need to be a combiner. This will strengthen the capacity of legal institutions to respond to human rights violations and bring perpetrators to justice. Furthermore, the field of remote sensing technology must look beyond the courts and tribunals by educating members from other disciplines like sociologists, demographers, and members from law enforcement and judicial agencies, such as judges, prosecutors, and paralegal professions. The value of satellite imaging for human rights and its use as evidence in legal proceedings need to be strengthened across the multidisciplinary dimensions.

Much of the research on remote sensing and its applications in counter-terrorism initiatives are based on data that was mainly derived by the experts in the field. Several computer algorithms are available, which determine what objects are present in satellite imagery. Effective data interpretation is very important in such cases where information is dynamic and dependent on many variables. Still, information gathered through remote sensing can increase transparency in the cases of counter-terrorism. However, many measures should be taken to understand and contextualize data as well as ensure its protection because of the sensitivity of the remote sensing-based information. The existing literature indicates a paucity of papers in which a deeper contextual analysis based on the socio-economic and historical data is conducted.

The use of visual images post facto as evidence of genocide, population displacement, environmental damage, the supplementation of the results with eyewitness and independent reports, and the versatility of the use of data are all examples of how important remote sensing has become in the domain of global peace and security. Though it is not novel for use as military means, it has only recently been incorporated into other areas, such as quantifying conflict zones. More research is needed regarding how to use remote sensing imagery as an early warning tool for conflict prevention. The credibility of remote sensing information and its application in court or by policymakers is still a grey region. In the field of peace and security, the need for strong communication between scientific applications and policymakers is crucial. The Eyes on Pakistan project is one of the successful examples of how remote sensing data documenting human rights violations have been used and publicized through an open-source platform accessible to public and government officials $[95,114]$.

Table 1. Major case studies associated with applications of remote sensing data in peace and security.

\begin{tabular}{cccccc}
\hline No. & Authors & Publication Year & Study Area & $\begin{array}{c}\text { Remote Sensing } \\
\text { Sensors }\end{array}$ & Methodologies \\
\hline 1 & Koch and El-Baz, [86] & 1998 & Kuwait & Landsat, SPOT & $\begin{array}{c}\text { Visual image } \\
\text { interpretation }\end{array}$ \\
\hline 2 & Bjorgo [43] & 2000 & Thailand & $\begin{array}{c}\text { Russian KVR-1000 } \\
\text { sensor }\end{array}$ & $\begin{array}{c}\text { Visual image } \\
\text { interpretation }\end{array}$ \\
\hline
\end{tabular}


Table 1. Cont

\begin{tabular}{|c|c|c|c|c|c|}
\hline No. & Authors & Publication Year & Study Area & $\begin{array}{l}\text { Remote Sensing } \\
\text { Sensors }\end{array}$ & Methodologies \\
\hline 3 & Giada et al. [45] & 2003 & Tanzania & IKONOS & $\begin{array}{l}\text { Supervised, unsupervised } \\
\text { image classification }\end{array}$ \\
\hline 4 & Schimmer R. [79] & 2006 & East Timor & Landsat & $\begin{array}{l}\text { Visual image } \\
\text { interpretation }\end{array}$ \\
\hline 5 & Schimmer R. [80] & 2008 & Darfur, Sudan & $\begin{array}{c}\text { MODIS, } \\
\text { SPOT-vegetation, } \\
\text { Climate data }\end{array}$ & $\begin{array}{c}\text { Temporal change in } \\
\text { vegetation phenology }\end{array}$ \\
\hline 6 & Prins [53] & 2008 & Darfur, Sudan & Landsat ETM+ & $\begin{array}{c}\text { Normalized burn ratio } \\
\text { (NBR) }\end{array}$ \\
\hline 7 & Anderson et al. [54] & 2008 & $\begin{array}{c}\text { Rift Valley } \\
\text { province, Kenya }\end{array}$ & MODIS & Active fire detection \\
\hline 8 & Madden et al. [83] & 2009 & Uganda & $\begin{array}{l}\text { Landsat, Google } \\
\text { Earth }\end{array}$ & Visual interpretation \\
\hline 9 & Schoepfer et al. [84] & 2010 & $\begin{array}{l}\text { The Democratic } \\
\text { Republic of the } \\
\text { Congo }\end{array}$ & $\begin{array}{l}\text { Rapideye, } \\
\text { Geoeye-1 }\end{array}$ & $\begin{array}{l}\text { Object-based image } \\
\text { classification }\end{array}$ \\
\hline 10 & Gorsevski et al. [48] & 2012 & $\begin{array}{l}\text { South Sudan and } \\
\text { Uganda border }\end{array}$ & $\begin{array}{c}\text { Landsat, MODIS, } \\
\text { Aerial } \\
\text { photographs }\end{array}$ & $\begin{array}{c}\text { Image classification, TCA, } \\
\text { disturbance index (DI), } \\
\text { NDVI }\end{array}$ \\
\hline 11 & Hagenlocher et al. [59] & 2012 & $\begin{array}{l}\text { Northern Darfur, } \\
\text { Sudan }\end{array}$ & QuickBird & $\begin{array}{c}\text { LULC, Object-based } \\
\text { image analysis (OBIA) }\end{array}$ \\
\hline 12 & Marx and Loboda [52] & 2013 & Darfur, Sudan & Landsat & Reflectance, TCA \\
\hline 13 & Jiang et al. [49] & 2017 & Yemen & NPP-VIIRS & $\begin{array}{c}\text { Theil-Sen Median } \\
\text { Trend Method, } \\
\text { Nighttime Light Indexes }\end{array}$ \\
\hline 14 & Casana et al. [60] & 2017 & $\begin{array}{l}\text { Southern Turkey, } \\
\text { Syria, and } \\
\text { Northern Iraq }\end{array}$ & $\begin{array}{l}\text { High-resolution } \\
\text { satellite } \\
\text { (DigitalGlobe) }\end{array}$ & Image interpretation \\
\hline 15 & Pech et al. [28] & 2017 & $\begin{array}{l}\text { Goma city, the } \\
\text { Democratic } \\
\text { Republic of the } \\
\text { Congo }\end{array}$ & $\begin{array}{c}\text { Landsat, } \\
\text { Worldview-2, } \\
\text { topographic maps }\end{array}$ & $\begin{array}{l}\text { Image processing and } \\
\text { visual interpretation }\end{array}$ \\
\hline 16 & Sawalhah et al. [39] & 2018 & Jordan & Landsat 8 & $\begin{array}{l}\text { Maximum likelihood } \\
\text { classification }\end{array}$ \\
\hline 17 & Levin et al. [31] & 2018 & Arab countries & $\begin{array}{l}\text { VIIRS, Flickr } \\
\text { photos }\end{array}$ & $\begin{array}{l}\text { Temporal trends in } \\
\text { monthly time-series }\end{array}$ \\
\hline 18 & Quinn et al. [46] & 2018 & NA & NA & Machine learning \\
\hline 19 & Hassan et al. [47] & 2018 & Bangladesh & $\begin{array}{l}\text { Sentinel-2A and } \\
\text { Sentinel-2B }\end{array}$ & $\begin{array}{l}\text { Random forest } \\
\text { classification }\end{array}$ \\
\hline 20 & Marx et al. [82] & 2019 & Rakhine, Myanmar & PlanetScope & $\begin{array}{l}\text { Pixel-based value } \\
\text { extraction }\end{array}$ \\
\hline 21 & Levin et al. [57] & 2019 & $\begin{array}{l}\text { World heritage } \\
\text { sites }\end{array}$ & $\begin{array}{l}\text { VIIRS, MODIS, } \\
\text { Global Terrorism } \\
\text { Database }\end{array}$ & Statistical analysis \\
\hline 22 & Prem et al. [50] & 2020 & Colombia & Landsat & Empirical model \\
\hline 23 & Shantnawi et al. [30] & 2020 & North Jordan & Landsat & $\begin{array}{l}\text { Supervised classification } \\
\text { and change analysis }\end{array}$ \\
\hline
\end{tabular}


Remote sensing techniques have been instrumental in supporting international treaties, monitoring crises, and predicting natural catastrophes. Various United Nations, governmental, and non-governmental organizations have shown a substantial interest in remote sensing technologies for international peace and security. The main purpose of these organizations is to provide scientific information toward international peace and security. The cooperation between various space agencies can provide useful information to decisionmakers, helping to establish global peace and security. For an example, the "International Charter Space and Major Disasters" platform provides satellite-based information for relief during humanitarian disasters. Satellite data are made available for rapid response to reduce disaster losses and damages. Advanced near real-time geospatial data can provide useful information to control the conflicts if combined with mobile data [115]. Big data initiatives can be helpful in conflict prevention and uncovering the relationship between conflict dynamics and development goals [116].

This review indicated that there has been significant progress in several technologies (like electronics, sensors, data analysis, and machine learning) being subsumed together with remote sensing applications for better understanding and realization of the project objective. However, the role of disciplines from social sciences and humanities along with remote sensing is still an underexplored territory. The absence of humanities somewhere also limits in understanding the key issues behind major conflicts and violence within a society. The future applications of remote sensing can be made more comprehensive by enriching the foundations with qualitative information from the ground level like issues with race, ethnicity, social structures, economic conditions, historical and anthropological foundations, and so on.

\section{Future Perspectives}

\subsection{Technology Development Perspective}

Advances in remote sensing technology rely on the development of improved sensors, imaging devices, and communication networks, among others. Some future perspectives in these areas are listed below.

\subsubsection{Use of New Sensors}

The remote sensing applications for international peace and security rely on the availability of accurate, reliable, fast, and high-resolution data from sensors. Advancements in sensor technology include the development of miniaturized sensors that reliably and accurately capture data with high spatial and temporal resolution. The terrestrial LiDAR sensors, which have been widely used in 3D city modeling, transport infrastructure mapping, vegetation mapping, and utility surveying, etc. will be effective tools for monitoring international peace and security. Such sensors are capable of collecting a 3D point cloud, which can be processed by state-of-the-art registration methods to reconstruct 3D surfaces. The 3D models are developed from 3D surfaces using computer graphics techniques. The 3D models help trace the location and extent of territories, avoid international border conflicts, and, hence, contribute toward peace and security [117]. The micro-electromechanical system (MEMS) technology [72], 3D sensors, and sensor fusion [118] are some of the notable areas, which are augmenting the remote sensing technology toward its role in international peace and security.

\subsubsection{UAV-Based Survey}

Unmanned Aerial vehicles (UAVs) have become more sophisticated during the last few decades [119]. The use of UAVs in the world's major military services for international security has been growing enormously. UAVs are being used to survey the battlefield remotely with a bundle of sensors mounted onto the aerial vehicle, giving adequate image resolution. An ensemble of tiny UAVs working with each other in collaboration is another technological advancement that can be used for remote sensing-based surveys for international peace and security applications. UAVs can be used to improve border control 
by monitoring large areas of border quickly and more efficiently than conventional means of border patrolling [120,121].

\subsubsection{Internet of Things (IoT) Based Survey}

The emergence of distributed computing has revolutionized the world across various domains. The use of the Internet of Things (IoT) in remote sensing applications for international peace and security is gaining popularity, enabled by the facility of cost-effective and reliable network services. The mitigation strategies, challenges, and risks of using IoT-based remote sensing for international peace and security have been disheveled [122].

\subsubsection{Visual Inertial System}

The role of the machine vision in inertial navigation systems for robotic vehicles dates back to the 1960s where cameras mounted on robotic vehicles were used for industrial inspection. The conventional cameras were replaced by 3D cameras, which were capable of capturing depth information along with intensity variation in the scene. The depth information is beneficial for the localization of objects in a scene and also overcomes the limitations of variation, in contrast to ambient light and parallax. However, in such systems, inertial drift is an issue as it makes the registration of consecutive scans erroneous. Leica Geosystems came up with a solution to overcome the problem of inertial drift with Visual Inertial System (VIS) technology. The technology uses five cameras along with an inertial measurement unit (IMU) to introduce a delta pose between two consecutive scans in real-time. It helps in the fusion of huge amounts of visual information very accurately, which can be used by various remote sensing applications for international peace and security [123].

\subsubsection{Simultaneous Localization and Mapping}

Simultaneous Localization and Mapping, commonly known as SLAM, is a computational technique that builds a map of an unknown environment along with tracking the position or movement of the camera in the environment. SLAM uses various kinds of sensors such as grayscale cameras, RGB cameras, radar, LiDAR, time-of-flight cameras, and monocular as 1 as stereo cameras to capture the scene. The feature points are extracted from the captured images using feature extraction and description algorithms, which are used to estimate the movement of features from one frame to another, and, hence, the movement of the camera. Using SLAM technology, the movement of objects can be accurately articulated in an environment, which finds enormous applications in monitoring international peace and security [124].

\subsection{Conflict Management Perspective}

By combining local socio-economic and historical information with remote sensing techniques can improve measurement validity and selection bias. This can potentially result in making it a major tool for conflict prevention, peacekeeping, peacemaking, and peace enforcement. It can provide the policymakers with better foresight or the future perspectives in some and/or the areas listed below.

\subsubsection{Conflict Prevention}

In the future, remote sensing should more actively be used to identify and monitor resources that might be the source of conflicts. Letouzé et al. [116] discussed the role of big data including geospatial information in conflict prevention. However, specific international cooperation and policy are required to avoid breaching national boundaries during such applications.

More research is needed on how to effectively use remote sensing techniques to prevent conflicts from happening. This may be an analysis of the regions known for recurring conflicts and identification of regions most likely to be hampered by future 
challenges of climate change. Furthermore, geographical indicators of possible sites with militant activity should be established [125].

\subsubsection{Peacekeeping}

A cluster of remote sensing satellites launched by the USA and Russia keeps the planet on a constant mode of surveillance. The sovereign nations often question this as espionage. However, the utility of remote sensing satellites for international peacekeeping efforts is commendable. To the extent of which international security norms and regulations permit, remote sensing research in areas with known militant activity should be enhanced through the improvement of data available for such regions and the creation of databases of similar research. In the future, remote sensing should also aid strategic positioning and monitoring of peace support operations (PSO) and disarmament, demobilization, and reintegration (DDR) [126].

\subsubsection{Peacemaking and Peace Enforcement}

The role of remote sensing in peacemaking and peace enforcement in many parts of the world has been pivotal for decades. Further case studies and examples of systematic exchange and sharing of conflict-related remote sensing data among both developing and the developed world can be helpful in the resolution of ongoing conflicts. Moreover, remote sensing can support and strengthen civil-military cooperation. With an increase in the number of satellites orbiting the earth, a huge amount of earth data has a significant potential for its use in peacemaking and peace enforcement. The synergistic approach of civilian science and remote sensing can help consolidate the environmental safety standards among the troubled regions [115].

\subsubsection{Peacebuilding}

Remote sensing will useful in post-conflict community rehabilitation like zoning, resource accessibility, and community planning. With the advancement in image processing algorithms, satellite imagery can be used in a better way than it was used a few decades ago for peacebuilding. Besides that, community project mapping by remote sensing should be considered to avoid project fatigue and duplication. In conflict zones, security aspects along with the political and social aspects influences the data collection. Here, remote sensing technology can be an enabler for exploring and assessing the risks to the ecosystem during uncertain and violent situations [115].

\section{Conclusions}

This review presents the applications of remote sensing technologies in supporting international peace and security missions and provided a detailed overview of each application with various case study examples from literature. In particular, we focused on earth observation for monitoring armed conflicts, human rights, tracking genocides, impact on environmental aspects and disease control preventions, and identified different interactions among these 4-level processes. This study noticed that the current research on peace and security issues is in the initial phase. Due to this reason, it is affected with incommensurate data for correspondence limiting granular information essential for characterization. Nevertheless, some recent studies have demonstrated the usefulness of high-resolution satellites in the area of refugee rehabilitation, quantifying conflict zones, and border security controls. With Kurmuk, Sudan as a case example, we also showed that the synergistic use of multi-source data from satellites, secondary sources, and ground-data could help in developing early warning systems to minimize civilian casualties in war zones. With the increased availability of higher spatial resolution images in the future, there is significant potential in space-borne technologies for early-warning of attacks, particularly for knowing the potential affected sites of targets.

On the other hand, near-real-time data provides useful information to rapid-response in relief activities and crisis management. Additionally, recent improvements in sensor 
capabilities make it an essential and relevant tool for documenting and preventing armed conflicts. The salient understanding from this study is that there is an ample requirement for disseminating information for ensuring prompt and efficient humanitarian responses at a global level. In particular, this is evident from Yemen civil conflicts. The Syrian crisis has the Sudan-South Sudan border issues and Rohingya crisis, etc. However, the initiatives on such works remain elusive with a lack of co-ordinate ion and setting between the geospatial community and relief organizations. It is hoped that initiatives such as the UNITAR/UNOSAT by United Nation, 'Not on Our Watch' funded the Satellite Sentinel Project (SSP), as a partnership among the Enough Project and DigitalGlobe, and the continuing upward trend in scientific work at the regional level (e.g., Witmer, [71]) will help to minimize the impact of crisis and disasters. Considerable capacity building for data processing, knowledge dissemination, and resource sharing is, therefore, required. Automated object-based analysis, data fusion algorithms, and tools to process Big Data in remote sensing are the way forward in terms of building a peaceful and secure world. This study concludes that remote sensing as a surveillance tool has immense potential to guard our planet's environment, peace, and security, provided it is used actively and transparently. The trajectory, intensity, and orientational control of those applications will depend on how the major stakeholders from academia, governance, and civil society converge to advance the foundational principles for conflict prevention, detection, and related human rights issues.

Author Contributions: Conceptualization, R.A., A.K. (Asma Kouser), D.S., and A.K. (Ashwani Kumar); Methodology, R.A., A.K. (Asma Kouser), D.S., A.P.Y. and A.K. (Ashwani Kumar); Formal analysis, R.A., A.K. (Ashwani Kumar), D.S., and P.M. Resources, R.A., A.K. (Asma Kouser), A.K. (Ashwani Kumar), D.S., P.M., A.G., A.P.Y., P.K., B.A.J., R.D., N.S., and A.B.R. Writing-original draft preparation, R.A., A.K. (Asma Kouser), D.S., A.P.Y. and A.K. (Ashwani Kumar); Writing-review and editing, R.A., A.K. (Asma Kouser), A.K. (Ashwani Kumar), D.S., P.M., A.G., A.P.Y., P.K., B.A.J., R.D., N.S., and A.B.R. All authors have read and agreed to the published version of the manuscript.

Funding: The publication fee was supported by the Publication Support Grants of Hokkaido University, Japan.

Data Availability Statement: The datasets generated in the current study are available from the corresponding author on request.

Acknowledgments: The authors are thankful to Planet Labs and Google Earth for providing satellite data and UNITAR/UNOSAT for reproducing the images. This work is supported by the Office for Developing Future Research Leaders (L-Station), SOUSEI Support Program for Young Researcher Hokkaido University, and Kurata Hitachi Foundation, Japan. The authors would like to thank Global Land Program-Japan Nodal Office and Young Sustainability Symposium (YSS-2020) for their support and collaboration. We are thankful to Rear Admiral Sanatan Kulshrestha (Former Director General Naval Armament Inspection-DGNIA, India) and Avinash Pandey (Asian Human Rights Commission-AHRC, Hong Kong) for their comments and suggestions. The authors extend sincere gratitude to the editor and anonymous reviewers for their constructive comments and valuable suggestions.

Conflicts of Interest: The authors declare no conflict of interest.

\section{References}

1. $\quad$ Lessnoff, M. Social Contract; Macmillan Education: London, UK, 1986; ISBN 978-0-333-36791-9.

2. Stokes, D.E. Pasteur's Quadrant: Basic Science and Technological Innovation; Brookings Institution Press: Washington, DC, USA, 2011; ISBN 978-0-8157-1907-6.

3. Barbier, E. Natural Resources and Economic Development; Cambridge University Press: Cambridge, UK, 2007; ISBN 978-0-521-70651-3.

4. The World Bank. World Development Report 1993: Investing in Health; The World Bank Group: Washington, DC, USA, $1993 ;$ Volume 1.

5. Kääb, A. Remote sensing of mountain environment. In Proceedings of the Projecting Global Change Impacts and Sustainable Land Use and Natural Resources Management in Mountain Biosphere Reserves, Pinos Genil, Spain, 14 March 2005; UNESCO: Pinos Genil, Spain; p. 92.

6. Campbell, J.B. Origins of Aerial Photographic Interpretation, U.S. Army, 1916 to 1918. Photogramm. Eng. Remote. Sens. 2008, 74, 77-93. [CrossRef] 
7. Stichelbaut, B. The application of First World War aerial photography to archaeology: The Belgian images. Antiquity 2006, 80, 161-172. [CrossRef]

8. Thomas, R.; Joseph, S.S. Emendation of undesirable attack on multiparty data sharing with anonymous Id assignment using AIDA algorithm. Innov. Syst. Des. Eng. 2015, 6, 6.

9. Lee, R.J.; Steele, S.L. Military use of satellite communications, remote sensing, and global positioning systems in the war on terror. J. Air L. Com. 2014, 79, 69.

10. Jasani, B.; Pesaresi, M.; Schneiderbauer, S.; Zeug, G. Remote Sensing from Space: Supporting International Peace and Security; Springer Science \& Business Media: Berlin/Heidelberg, Germany, 2009; ISBN 1-4020-8484-6.

11. Dashora, A.; Lohani, B.; Malik, J.N. A repository of earth resource information-CORONA satellite programme. Curr. Sci. 2007, 92, 926-932.

12. Roy, S. The Palestinian-Israeli Conflict and Palestinian socioeconomic decline: A place denied. Int. J. Politics Cult. Soc. 2003, 17, 365-403. [CrossRef]

13. Singhal, A. In Search of Military GIS. Geospat. World 2009. Available online: https://www.geospatialworld.net/article/in-searchof-military-gis / (accessed on 5 May 2020).

14. United Nations (Ed.) Handbook on Geospatial Infrastructure in Support of Census Activities; Studies in Methods, Series F; United Nations: New York, NY, USA, 2009; ISBN 978-92-1-161527-2.

15. Rizi, S.M.M.; Geller, A. Merging Remote Sensing Data and Population Surveys in Large, Empirical Multiagent Models: The Case of the Afghan Drug Industry; George Mason University: Fairfax, VA, USA, 2010; p. 8.

16. Brown, I. Assessing eco-scarcity as a cause of the outbreak of conflict in Darfur: A remote sensing approach. Int. J. Remote. Sens. 2010, 31, 2513-2520. [CrossRef]

17. Soytong, P.; Perera, R. Use of GIS tools for environmental conflict resolution at map ta phut industrial zone in Thailand. Sustainability 2014, 6, 2435-2458. [CrossRef]

18. Hay, S.I. Remote sensing and disease control: Past, present and future. Trans. R. Soc. Trop. Med. Hyg. 1997, 91, 105-106. [CrossRef]

19. Sulik, J.J.; Edwards, S. Feature extraction for Darfur: Geospatial applications in the documentation of human rights abuses. Int. J. Remote Sens. 2010, 31, 2521-2533. [CrossRef]

20. Annual Report of the United Nations High Commissioner for Human Rights and Reports of the Office of the High Commissioner and the Secretary-General; Report on the Prevention of Genocide; Human Rights Council: Geneva, Switzerland, 2019.

21. UNEP (United Nations Environment Programme). The Environmental Food Crisis: The Environment's Role in Averting Future Food Crises: A UNEP Rapid Response Assessment; UNEP/Earthprint: Nairobi, Kenya, 2009; ISBN 978-82-7701-054-0.

22. Hettling, J.K. The use of remote sensing satellites for verification in international law. Space Policy 2003, 19, 33-39. [CrossRef]

23. Avtar, R.; Sahu, N.; Aggarwal, A.K.; Chakraborty, S.; Kharrazi, A.; Yunus, A.P.; Dou, J.; Kurniawan, T.A. Exploring renewable energy resources using remote sensing and GIS-A review. Resources 2019, 8, 149. [CrossRef]

24. Estoque, R.C. A review of the sustainability concept and the state of SDG monitoring using remote sensing. Remote Sens. 2020, 12, 1770. [CrossRef]

25. Avtar, R.; Aggarwal, R.; Kharrazi, A.; Kumar, P.; Kurniawan, T.A. Utilizing geospatial information to implement SDGs and monitor their Progress. Environ. Monit. Assess. 2020, 192, 35. [CrossRef]

26. Jasani, B.; Larsson, C. Security implications of remote sensing. Space Policy 1988, 4, 46-59. [CrossRef]

27. Abramson, S.F.; Carter, D.B. The historical origins of territorial disputes. Am. Political Sci. Rev. 2016, 110, 675-698. [CrossRef]

28. Pech, L.; Lakes, T. The impact of armed conflict and forced migration on urban expansion in Goma: Introduction to a simple method of satellite-imagery analysis as a complement to field research. Appl. Geogr. 2017, 88, 161-173. [CrossRef]

29. Sawalhah, M.N.; Al-Kofahi, S.D.; Othman, Y.A.; Cibils, A.F. Assessing rangeland cover conversion in Jordan after the Arab spring using a remote sensing approach. J. Arid. Environ. 2018, 157, 97-102. [CrossRef]

30. Shatnawi, N.; Weidner, U.; Hinz, S. Monitoring urban expansion as a result of refugee fluxes in north jordan using remote sensing techniques. J. Urban. Plan. Dev. 2020, 146, 04020026. [CrossRef]

31. Levin, N.; Ali, S.H.; Crandall, D. Utilizing remote sensing and big data to quantify conflict intensity: The Arab Spring as a case study. Appl. Geogr. 2018, 94, 1-17. [CrossRef]

32. Weidmann, N.B.; Rød, J.K.; Cederman, L.-E. Representing ethnic groups in space: A new dataset. J. Peace Res. 2010, 47, 491-499. [CrossRef]

33. Avtar, R.; Komolafe, A.A.; Kouser, A.; Singh, D.; Yunus, A.P.; Dou, J.; Kumar, P.; Das Gupta, R.; Johnson, B.A.; Minh, H.V.T.; et al. Assessing sustainable development prospects through remote sensing: A review. Remote. Sens. Appl. Soc. Environ. 2020, 20, 100402. [CrossRef]

34. Starr, H. Opportunity, willingness and geographic information systems (GIS): Reconceptualizing borders in international relations. Politi. Geogr. 2002, 21, 243-261. [CrossRef]

35. Branch, J. Geographic information systems (GIS) in international relations. Int. Organ. 2016, 70, 845-869. [CrossRef]

36. Baldwin, D.A. The concept of security. Rev. Int. Stud. 1997, 23, 5-26. [CrossRef]

37. Anderson, R. A Definition of peace. Peace Confl. 2004, 10, 101. [CrossRef]

38. White, N.D. Keeping the Peace: The United Nations and the Maintenance of International Peace and Security; Manchester University Press: Manchester, UK, 1997. 
39. Galtung, J.; Fischer, D. Positive and negative peace. In Johan Galtung; SpringerBriefs on Pioneers in Science and Practice; Springer: Berlin/Heidelberg, Germany, 2013; Volume 5, pp. 173-178. ISBN 978-3-642-32480-2.

40. Thomas, C.; Wilkin, P. Globalization, Human Security, and the African Experience; Lynne Rienner Publishers: Boulder, CO, USA, 1999; ISBN 1-55587-699-4.

41. Cederman, L.-E.; Gleditsch, K.S.; Buhaug, H. Inequality, Grievances, and Civil War; Cambridge Studies in Contentious Politics; Cambridge University Press: New York, NY, USA, 2013; ISBN 978-1-107-01742-9.

42. Dalen, Ø.; Johannessen, O.; Bjørgo, E.; Babiker, M.; Andersen, G. Use of ERS SAR Imagery in Refugee Relief; ESTEC: Nordwijk, The Netherlands, 2000.

43. Bjorgo, E. Using very high spatial resolution multispectral satellite sensor imagery to monitor refugee camps. Int. J. Remote Sens. 2000, 21, 611-616. [CrossRef]

44. Dysart, M.D. Remote Sensing and Mass Migration Policy Development; Air War College, Air University: Montgomery, AL, USA, 2012.

45. Giada, S.; De Groeve, T.; Ehrlich, D.; Soille, P. Information extraction from very high resolution satellite imagery over Lukole refugee camp, Tanzania. Int. J. Remote Sens. 2003, 24, 4251-4266. [CrossRef]

46. Quinn, J.A.; Nyhan, M.M.; Navarro, C.; Coluccia, D.; Bromley, L.; Luengo-Oroz, M. Humanitarian applications of machine learning with remote-sensing data: Review and case study in refugee settlement mapping. Philos. Trans. R. Soc. A Math. Phys. Eng. Sci. 2018, 376, 20170363. [CrossRef]

47. Hassan, M.M.; Smith, A.C.; Walker, K.; Rahman, M.K.; Southworth, J. Rohingya refugee crisis and forest cover change in Teknaf, Bangladesh. Remote Sens. 2018, 10, 689. [CrossRef]

48. Gorsevski, V.; Kasischke, E.S.; Dempewolf, J.; Loboda, T.; Grossmann, F. Analysis of the Impacts of armed conflict on the Eastern Afromontane forest region on the South Sudan-Uganda border using multitemporal Landsat imagery. Remote Sens. Environ. 2012, 118, 10-20. [CrossRef]

49. Jiang, W.; He, G.; Long, T.; Liu, H. Ongoing conflict makes yemen dark: From the perspective of nighttime light. Remote Sens. 2017, 9, 798. [CrossRef]

50. Prem, M.; Saavedra, S.; Vargas, J.F. End-of-conflict deforestation: Evidence from Colombia's peace agreement. World Dev. 2020, 129, 104852. [CrossRef]

51. Bromley, D.W. Environment and Economy: Property Rights and Public Policy; Basil Blackwell Ltd., University of Wisconsin-Madison: Madison, WI, USA, 1991.

52. Marx, A.; Loboda, T. Landsat-based early warning system to detect the destruction of villages in Darfur, Sudan. Remote Sens. Environ. 2013, 136, 126-134. [CrossRef]

53. Prins, E. Use of low cost Landsat ETM+ to spot burnt villages in Darfur, Sudan. Int. J. Remote Sens. 2007, 29, 1207-1214. [CrossRef]

54. Anderson, D.M.; Lochery, E. Violence and exodus in Kenya's rift valley, 2008: Predictable and preventable? J. East. Afr. Stud. 2008, 2, 328-343. [CrossRef]

55. Lee, C.; De Vries, W.T. Bridging the semantic gap between land tenure and EO data: Conceptual and methodological underpinnings for a geospatially informed analysis. Remote Sens. 2020, 12, 255. [CrossRef]

56. Avtar, R.; Singh, D.; Umarhadi, D.A.; Yunus, A.P.; Misra, P.; Desai, P.N.; Kouser, A.; Kurniawan, T.A.; Phanindra, K. Impact of COVID-19 lockdown on the fisheries sector: A case study from three harbors in western India. Remote Sens. 2021, 13, 183. [CrossRef]

57. Levin, N.; Ali, S.H.; Crandall, D.; Kark, S. World Heritage in danger: Big data and remote sensing can help protect sites in conflict zones. Glob. Environ. Chang. 2019, 55, 97-104. [CrossRef]

58. Knoth, C. Combining automatic and manual image analysis in a web-mapping application for collaborative conflict damage assessment. Appl. Geogr. 2018, 97, 25-34. [CrossRef]

59. Hagenlocher, M.; Lang, S.; Tiede, D. Integrated assessment of the environmental impact of an IDP camp in Sudan based on very high resolution multi-temporal satellite imagery. Remote Sens. Environ. 2012, 126, 27-38. [CrossRef]

60. Casana, J.; Laugier, E.J. Satellite imagery-based monitoring of archaeological site damage in the Syrian civil war. PLoS ONE 2017, 12, e0188589. [CrossRef]

61. Xu, Y.; Knudby, A.; Côté-Lussier, C. Mapping ambient light at night using field observations and high-resolution remote sensing imagery for studies of urban environments. Build. Environ. 2018, 145, 104-114. [CrossRef]

62. Do, Q.-T.; Shapiro, J.N.; Elvidge, C.D.; Abdel-Jelil, M.; Ahn, D.P.; Baugh, K.E.; Hansen-Lewis, J.; Zhizhin, M.; Bazilian, M.D. Terrorism, geopolitics, and oil security: Using remote sensing to estimate oil production of the Islamic State. Energy Res. Soc. Sci. 2018, 44, 411-418. [CrossRef]

63. Benítez, P.C.; McCallum, I.; Obersteiner, M.; Yamagata, Y. Global potential for carbon sequestration: Geographical distribution, country risk and policy implications. Ecol. Econ. 2007, 60, 572-583. [CrossRef]

64. Hu, Z.D.; Ge, Y.J. Geopolitical Energy Security Evaluation Method and Its Application Based on Politics of Scale. Int. Arch. Photogramm. Remote. Sens. Spat. Inf. Sci. 2013, XL-4/W3, 79-81. [CrossRef]

65. Moisio, S.; Harle, V. The limits of geopolitical remote sensing. Eurasian Geogr. Econ. 2006, 47, 204-210. [CrossRef]

66. Colomina, I.; Molina, P. Unmanned aerial systems for photogrammetry and remote sensing: A review. ISPRS J. Photogramm. Remote Sens. 2014, 92, 79-97. [CrossRef] 
67. Antonsich, M. In Defense of “Geopolitical Remote Sensing": Reply to Moisio and Harle. Eurasian Geogr. Econ. 2006, 47, 211-215. [CrossRef]

68. Keeley, J.F. The use of commercial satellite imagery and Canadian security needs. In Commercial Satellite Imagery and United Nations Peacekeeping: A View from Above; Keeley, J.F., Huebert, R., Eds.; Ashgate: Aldershot, UK, 2004; pp. 87-98.

69. Melillos, G.; Themistocleous, K.; Papadavid, G.; Agapiou, A.; Prodromou, M.; Michaelides, S.; Hadjimitsis, D.G. Integrated Use of Field Spectroscopy and Satellite Remote Sensing for Defence and Security Applications in Cyprus; Themistocleous, K., Hadjimitsis, D.G., Michaelides, S., Papadavid, G., Eds.; SPIE: Paphos, Cyprus, 2016; p. 96880F.

70. Al-Rodhan, N.R.F. Meta-Geopolitics of Outer Space: An Analysis of Space Power, Security and Governance; Palgrave Macmillan: London, UK, 2012; ISBN 978-1-349-33967-9.

71. Witmer, F.D. Remote sensing of violent conflict: Eyes from above. Int. J. Remote Sens. 2015, 36, 2326-2352. [CrossRef]

72. Zhang, X.; Xie, J.; Li, C.; Xu, R.; Zhang, Y.; Liu, S.; Wang, J. MEMS-based super-resolution remote sensing system using compressive sensing. Opt. Commun. 2018, 426, 410-417. [CrossRef]

73. Cantelli, L.; Mangiameli, M.; Melita, C.D.; Muscato, G. UAV/UGV Cooperation for Surveying Operations in Humanitarian Demining. In Proceedings of the 2013 IEEE International Symposium on Safety, Security, and Rescue Robotics (SSRR), Linkoping, Sweden, 21-26 October 2013; IEEE: Linkoping, Sweden; pp. 1-6.

74. Ibrahim, A.A.; Haruna, A. The united nations and the challenges of global peace, security and development. Res. Humanit. Soc. Sci. 2014, 4 .

75. Satellite Sentinel Project (SSP). Troops in the Demilitarized Zone Confirmation of Violations by Sudan and South Sudan; Satellite Sentinel Project (SSP); Harvard Humanitarian Initiative: Cambridge, MA, USA, 2013; p. 23.

76. Satellite Sentinel Project (SSP). Radius of Operations: Sudan Increases Air Attack Capacity; Satellite Sentinel Project (SSP); Harvard Humanitarian Initiative: Cambridge, MA, USA, 2011; p. 8.

77. Som, V. Chinese troops withdraw $2 \mathrm{Km}$ in Galwan Valley, show new satellite images. Indian Express 2020.

78. Adu-Amanfoh, F. The Roles of Peace and Security, Political Leadership, and Entrepreneurship in the Socio-Economic Development of Emerging Countries: A Compendium of Lessons Learnt from Sub-Saharan Africa; AuthorHouse: Bloomington, IN, USA, 2014; ISBN 978-1-4918-9160-5.

79. Russell, S. Violence by Fire in East Timor, September 8, 1999; Crimes against Humanity; Yale University: New Haven, CT, USA, 2006; p. 17.

80. Schimmer, R. Tracking the Genocide in Darfur: Population Displacement as Recorded by Remote Sensing; Yale Center for International and Area Studies New Haven: New Haven, CT, USA, 2008; p. 52.

81. Marx, A.; Goward, S. Remote sensing in human rights and international humanitarian law monitoring: Concepts and methods. Geogr. Rev. 2013, 103, 100-111. [CrossRef]

82. Marx, A.; Windisch, R.; Kim, J.S. Detecting village burnings with high-cadence smallsats: A case-study in the Rakhine State of Myanmar. Remote. Sens. Appl. Soc. Environ. 2019, 14, 119-125. [CrossRef]

83. Madden, M.; Ross, A. Genocide and GIScience: Integrating personal narratives and geographic information science to study human rights. Prof. Geogr. 2009, 61, 508-526. [CrossRef]

84. Schoepfer, E.; Kranz, O.; Addink, E.; Coillie, F. Monitoring natural resources in conflict using an object-based multi-scale image analysis approach. Proc. GEOBIA 2010.

85. Elvidge, C.D.; Zhizhin, M.; Baugh, K.E.; Hsu, F.-C. Automatic boat identification system for VIIRS low light imaging data. Remote. Sens. 2015, 7, 3020-3036. [CrossRef]

86. Koch, M.; El-Baz, F. Identifying the effects of the gulf war on the geomorphic features of kuwait by remote sensing and GIS. Photogramm. Eng. Remote Sens. 1998, 64, 739-746.

87. Yasmi, Y.; Schanz, H. Managing conflict escalation in forestry: Logging versus local community interests in Baru Pelepat village, Sumatra, Indonesia. Int. J. Biodivers. Sci. Ecosyst. Serv. Manag. 2010, 6, 43-51. [CrossRef]

88. Luo, L.; Wang, X.; Guo, H.; Lasaponara, R.; Shi, P.; Bachagha, N.; Li, L.; Yao, Y.; Masini, N.; Chen, F.; et al. Google Earth as a powerful tool for archaeological and cultural heritage applications: A review. Remote. Sens. 2018, 10, 1558. [CrossRef]

89. Amnesty International Nigeria. Gruesome Footage Implicates Military in War Crimes. Available online: https:/ / www.amnesty. org/en/latest/news/2014/08/nigeria-gruesome-footage-implicates-military-war-crimes / (accessed on 19 August 2019).

90. Nunez, A.C.N. Admissibility of Remote Sensing Evidence before International and Regional Tribunals; Innovations in Human Rights Monitoring; Amnesty International: New York, NY, USA, 2012.

91. American Association for the Advancement for Science (AAAS). Geospatial Technologies and Human Rights. Available online: https:/ / www.aaas.org/programs / geospatial-technologies (accessed on 15 August 2019).

92. American Association for the Advancement for Science (AAAS). Satellite Imagery and Possible Mass Graves in Sheberghan, Afghanistan; Scientific Responsibility, Human Rights \& Law Program; American Association for the Advancement of Science: Washington, DC, USA, 2020.

93. American Association for the Advancement for Science (AAAS). High-Resolution Satellite Imagery and the Conflict in Eastern Burma; Scientific Responsibility, Human Rights \& Law Program; American Association for the Advancement of Science: Washington, DC, USA, 2020. 
94. American Association for the Advancement for Science (AAAS). Geospatial Technologies and Human Rights—North Korea's Prison Camps Case Study Summary; Scientific Responsibility, Human Rights \& Law Program; American Association for the Advancement of Science: Washington, DC, USA, 2020.

95. American Association for the Advancement for Science (AAAS). Geovisualization for Mapping Human Rights Incidents in Northwestern Pakistan; Scientific Responsibility, Human Rights \& Law Program; American Association for the Advancement of Science: Washington, DC, USA, 2020.

96. Wang, B.Y.; Raymond, N.; Gould, G.; Baker, I. Problems from hell, solution in the heavens?: Identifying obstacles and opportunities for employing geospatial technologies to document and mitigate mass atrocities. Stability: Int. J. Secur. Dev. 2013, 2, 18. [CrossRef]

97. Satellite Sentinel Project (SSP). Cover-Up: New Evidence of Three Mass Graves in South Kordofan; Harvard Humanitarian Initiative: Cambridge, MA, USA, 2011; p. 10.

98. Sandalinas, J. Satellite imagery and its use as evidence in the proceedings of the international criminal court. ZLW 2015, 64, 666.

99. Pavone, I.R. Infectious diseases as a new threat to international peace and security: The security council and the securitization of health. Fachinf. Int. Interdiszip. Rechtsforschung Völkerrechtsblog 2016. [CrossRef]

100. Dister, S.W.; Beck, L.R.; Wood, B.L.; Falco, R.; Fish, D. The use of GIS and remote sensing technologies in a landscape approach to the study of Lyme disease transmission risk. Proc. GIS 1993, 93, 15-18.

101. Bhunia, G.S.; Shit, P.K. Introduction to geoinformatics in public health. In Geospatial Analysis of Public Health; Bhunia, G.S., Shit, P.K., Eds.; Springer International Publishing: Cham, Switzerland, 2019; pp. 1-27. ISBN 978-3-030-01680-7.

102. Beck, L.R.; Rodriguez, M.H.; Dister, S.W.; Rodriguez, A.D.; Rejmankova, E.; Ulloa, A.; Meza, R.A.; Roberts, D.R.; Paris, J.F.; Spanner, M.A.; et al. Remote sensing as a landscape epidemiologic tool to identify villages at high risk for malaria transmission. Am. J. Trop. Med. Hyg. 1994, 51, 271-280. [CrossRef] [PubMed]

103. Dlamini, S.N.; Beloconi, A.; Mabaso, S.; Vounatsou, P.; Impouma, B.; Fall, I.S. Review of remotely sensed data products for disease mapping and epidemiology. Remote. Sens. Appl. Soc. Environ. 2019, 14, 108-118. [CrossRef]

104. Kotchi, S.O.; Bouchard, C.; Ludwig, A.; Rees, E.E.; Brazeau, S. Using Earth observation images to inform risk assessment and mapping of climate change-related infectious diseases. Can. Commun. Dis. Rep. 2019, 45, 133-142. [CrossRef]

105. Avtar, R.; Kumar, P.; Supe, H.; Dou, J.; Sahu, N.; Mishra, B.K.; Yunus, A.P. Did the COVID-19 lockdown-induced hydrological residence time intensify the primary productivity in lakes? Observational results based on satellite remote sensing. Water 2020, 12, 2573. [CrossRef]

106. Avtar, R.; Herath, S.; Saito, O.; Gera, W.; Singh, G.; Mishra, B.; Takeuchi, K. Application of remote sensing techniques toward the role of traditional water bodies with respect to vegetation conditions. Environ. Dev. Sustain. 2014, 16, 995-1011. [CrossRef]

107. Caballero-Leiva, I.; Marrero Betancort, N.; Rodriguez Betancor, J.J.; Rodríguez Esparragón, D.; Marcello Ruiz, F.J. An Approximation to the Relationship Between Climatic Variables Obtained Through Remote Satellite Sensors and Hospital Admissions: A Case Study on Gran Canaria Island. Sens. Transducers 2019, 238, 80-86.

108. Bhunia, G.S.; Shit, P.K. Exploring ecology and associated disease pattern. In Geospatial Analysis of Public Health; Bhunia, G.S., Shit, P.K., Eds.; Springer International Publishing: Cham, Switzerland, 2019; pp. 139-198. ISBN 978-3-030-01680-7.

109. Racault, M.F.; Abdulaziz, A.; George, G.; Menon, N.; Punathil, M.; McConville, K.; Loveday, B.; Platt, T.; Sathyendranath, S.; Vijayan, V. Environmental reservoirs of vibrio cholerae: Challenges and opportunities for ocean-color remote sensing. Remote Sens. 2019, 11, 2763. [CrossRef]

110. Beck, L. Remote sensing and human health: New sensors and new opportunities. Emerg. Infect. Dis. 2000, 6, 217-227. [CrossRef]

111. Igarashi, T.; Kuze, A.; Sobue, S.; Yamamoto, A.; Yamamoto, K.; Oyoshi, K.; Imaoka, K.; Fukuda, T. Japan's efforts to promote global health using satellite remote sensing data from the Japan Aerospace Exploration Agency for prediction of infectious diseases and air quality. Geospat. Health 2014, 8, 603-610. [CrossRef]

112. Jamieson, P.D. Lucrative Targets: The U.S. Air Force in the Kuwaiti Theater of Operations; The USAF in the Persian Gulf War; Air Force History and Museums Program: Washington, DC, USA, 2001; ISBN 978-0-16-050958-2.

113. Marolda, E.J. By Sea, Air, and Land: An Illustrated History of the U.S. Navy and the War in Southeast Asia; Naval Historical Center, Dept. of the Navy: For Sales by Supt. of Docs.; U.S. G.P.O.: Washington, DC, USA, 1994; ISBN 978-0-945274-09-4.

114. American Association for the Advancement for Science (AAAS). AAAS, Amnesty Use Geo-Visualization to Shed Light on Human Rights in Pakistan; Scientific Responsibility, Human Rights \& Law Program; American Association for the Advancement of Science: Washington, DC, USA, 2010.

115. Weir, D.; McQuillan, D.; Francis, R.A. Civilian science: The potential of participatory environmental monitoring in areas affected by armed conflicts. Environ. Monit. Assess. 2019, 191, 1-17. [CrossRef]

116. Letouzé, E.; Meier, P.; Vinck, P. Big Data for Conflict Prevention: New Technology and the Prevention of Violence and Conflict; International Peace Institute: New York, NY, USA, 2013; pp. 4-27.

117. Wang, Y.; Chen, Q.; Zhu, Q.; Liu, L.; Li, C.; Zheng, D. A survey of mobile laser scanning applications and key techniques over urban areas. Remote Sens. 2019, 11, 1540. [CrossRef]

118. Rasti, B.; Ghamisi, P. Remote sensing image classification using subspace sensor fusion. Inf. Fusion 2020, 64, 121-130. [CrossRef]

119. Avtar, R.; Watanabe, T. Unmanned Aerial Vehicle: Applications in Agriculture and Environment; Springer: Berlin/Heidelberg, Germany, 2020.

120. Bassoli, R.; Sacchi, C.; Granelli, F.; Ashkenazi, I. A Virtualized Border Control System Based on UAVs: Design and Energy Efficiency Considerations. In Proceedings of the 2019 IEEE Aerospace Conference, Big Sky, MT, USA, 2 March 2019 ; pp. 1-11. 
121. Koslowski, R.; Schulzke, M. Drones Along Borders: Border Security UAVs in the United States and the European Union. Int. Stud. Perspect. 2018, 19, 305-324. [CrossRef]

122. Abdelzaher, T.; Ayanian, N.; Basar, T.; Diggavi, S.; Diesner, J.; Ganesan, D.; Govindan, R.; Jha, S.; Lepoint, T.; Marlin, B.; et al. Will Distributed Computing Revolutionize Peace? The Emergence of Battlefield IoT. In Proceedings of the 2018 IEEE 38 th International Conference on Distributed Computing Systems (ICDCS), Vienna, Austria, 2 July 2018; pp. 1129-1138.

123. Xiao, L.; Wang, J.; Qiu, X.; Rong, Z.; Zou, X. Dynamic-SLAM: Semantic monocular visual localization and mapping based on deep learning in dynamic environment. Robot. Auton. Syst. 2019, 117, 1-16. [CrossRef]

124. Cen, R.; Zhang, X.; Tao, Y.; Xue, F.; Zhang, Y. Temporal delay estimation of sparse direct visual inertial odometry for mobile robots. J. Frankl. Inst. 2020, 357, 3893-3906. [CrossRef]

125. Langford, R.E. Introduction to Weapons of Mass Destruction: Radiological, Chemical, and Biological; Wiley-Interscience: Hoboken, NJ, USA, 2004; ISBN 978-0-471-46560-7.

126. Rufer, R. Disarmament, Demobilisation and Reintegration (DDR): Conceptual Approaches, Specific Settings, Practical Experiences; Geneva Centre for the Democratic Control of Armed Forces (DCAF): Geneva, Switzerland, 2005; p. 116. 